\title{
Summary of Suspended-Solids Concentration Data, San Francisco Bay, California, Water Year 1995
}

By Paul A. Buchanan and David H. Schoellhamer

U.S. GEOLOGICAL SURVEY

Open-File Report 96-591

Prepared in cooperation with the SAN FRANCISCO REGIONAL WATER QUALITY CONTROL BOARD and the U.S. ARMY CORPS OF ENGINEERS

कீ

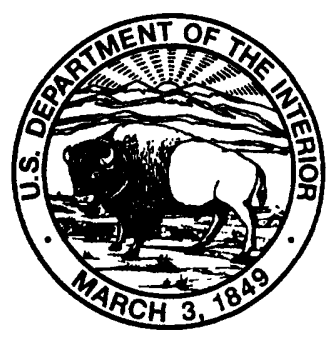




\title{
U.S. DEPARTMENT OF THE INTERIOR BRUCE BABBITT, Secretary
}

\author{
U.S. GEOLOGICAL SURVEY \\ Gordon P. Eaton, Director
}

The use of firm, trade, and brand names in this report is for identification purposes only and does not constitute endorsement by the U.S. Geological Survey

For additional information write to:

\section{District Chief}

U.S. Geological Survey

Federal Building, Room W-2233

2800 Cottage Way

Sacramento, CA 95825
Copies of this report can be purchased from:

U.S. Geological Survey

Information Services

Box 25286

Federal Center

Denver, CO 80225 


\title{
United States Department of the Interior
}

\author{
U.S. GEOLOGICAL SURVEY \\ WATER RESOURCES DIVISION \\ District Office \\ Federal Building, Room W-2233 \\ 2800 Cottage Way \\ Sacramento, California 95825 \\ (916) $979-2605$ \\ Fax (916) 979-2669 \\ http://water.wr.usgs.gov
}

For Release: Immediately

For more information call:

Paul Buchanan

Mailed:

(916) 979-3025

\section{SUSPENDED SOLIDS IN SAN FRANCISCO BAY MEASURED}

A report summarizing suspended-solids concentrations in San Francisco Bay from October 1994 through September 1995 has been published by the U.S. Geological Survey, Department of the Interior. Suspended solids, which are sediments and organic matter moving in the bay water, are important because they transport adsorbed contaminants, such as metals and pesticides, provide the habitat for benthic organisms, limit light availability and photosynthesis, and deposit in ports and shipping channels, which require dredging.

Suspended-solids concentrations were measured at Mallard Island, Martinez, Point San Pablo, San Francisco Pier 24, San Mateo Bridge, a shallow-water site in South San Francisco Bay, Dumbarton Bridge, and at a channel marker south of the Dumbarton Bridge. Measurements were collected every 15 minutes from optical sensors positioned at mid-depth and near the bottom of the bay. The suspended-solids concentration data will be used by the U.S. Geological Survey to determine the factors that affect suspended-solids concentrations in San Francisco Bay and to help develop numerical models of the bay. These data were collected in cooperation with the San Francisco Regional Water Quality Control Board, the Interagency Ecological Program, and the U.S. Army Corps of Engineers. 
Copies of U.S. Geological Survey Open-File Report 96-591, “Summary of Suspended-Solids Concentration Data, San Francisco Bay, California, Water Year 1995," by Paul A. Buchanan and David H. Schoellhamer, are available for purchase from the U.S. Geological Survey, Branch of Information Services, Box 25286, Denver, CO 80225-0286. The price of the paper copy is $\$ \_$; microfiche is $\$ \_$. When ordering, please mention the open-file report number and complete title of the report. Prepayment is required. Check or money order, in the exact amount, should be made payable to U.S. Geological Survey, Department of Interior. The report is available for inspection at the following offices and libraries:

U.S. Geological Survey Library Room 4A100, National Center 12201 Sunrise Valley Drive

Reston, VA 22092

U.S. Geological Survey Library 345 Middlefield Road

Menlo Park, CA 94025

U.S. Geological Survey

Federal Center

Room C2202, Building 20

Lakewood, CO 80225
U.S. Geological Survey

Federal Building, Room W-2233

2800 Cottage Way

Sacramento, CA 95825

U.S. Geological Survey

4735 Kearny Villa Road, Suite O

San Diego, CA 92123

Natural Resources Library

Gifts and Exchange Section

18th and C Streets, NW

Washington, DC 20240 


\section{CONTENTS}

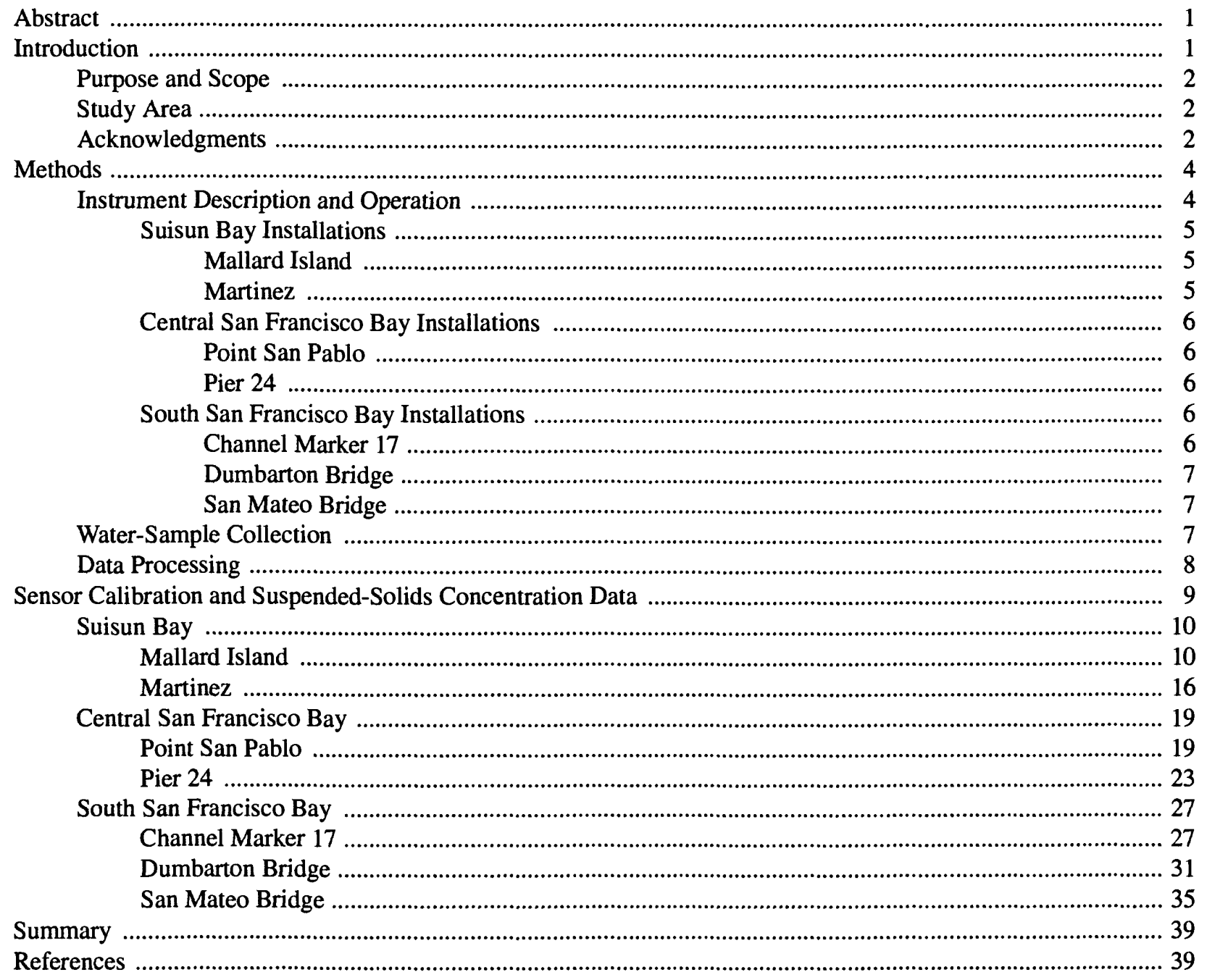

FIGURES

1. Map showing San Francisco Bay study area ......................................................................................... 3

2-31. Graphs showing:

2. Raw and edited optical backscatterance data, mid-depth sensor, Point San Pablo,

Central San Francisco Bay, California, water year 1994 .................................................................. 8

3. Calibration of near-surface optical backscatterance sensor (with wiper) at Mallard Island, Suisun Bay, California, water year 1995

4. Calibration of the near-surface optical backscatterance sensor (with wiper) during flood at Mallard Island, Suisun Bay, California, water year 1995

5. Calibration of near-bottom optical backscatterance sensor (with wiper) at Mallard Island, Suisun Bay, California, water year 1995

6. Calibration of near-bottom optical backscatterance sensor (with wiper) during flood at Mallard Island, Suisun Bay, California, water year 1995

7. Time series of near-surface suspended-solids concentration calculated from sensor readings at Mallard Island, Suisun Bay, California, water year 1995 
8. Time series of near-bottom suspended-solids concentration calculated from sensor readings at Mallard Island, Suisun Bay, California, water year 1995

9. Calibration of near-surface optical backscatterance sensor (with wiper) at Martinez, Suisun Bay, California, water year 1995

10. Calibration of near-surface optical backscatterance sensor (with wiper) during flood at Martinez, Suisun Bay, California, water year 1995

11. Time series of near-surface suspended-solids concentration calculated from sensor readings at Martinez, Suisun Bay, California, water year 1995

12. Calibration of mid-depth optical backscatterance sensor at Point San Pablo, Central San Francisco Bay, California, water year 1995

13. Calibration of near-bottom optical backscatterance sensor at Point San Pablo, Central San Francisco Bay, California, water year 1995

14. Time series of mid-depth suspended-solids concentration calculated from sensor readings at Point San Pablo, Central San Francisco Bay, California, water year 1995

15. Time series of near-bottom suspended-solids concentration calculated from sensor readings at Point San Pablo, Central San Francisco Bay, California, water year 1995

16. Calibration of mid-depth optical backscatterance sensor at Pier 24, Central San Francisco Bay, California, water year 1995

17. Calibration of near-bottom optical backscatterance sensor at Pier 24, Central San Francisco Bay, California, water year 1995

18. Time series of mid-depth suspended-solids concentration calculated from sensor readings at Pier 24, Central San Francisco Bay, California, water year 1995

19. Time series of near-bottom suspended-solids concentration calculated from sensor readings at Pier 24, Central San Francisco Bay, California, water year 1995

20. Calibration of mid-depth optical backscatterance sensor at channel marker 17, South San Francisco Bay, California, water year 1995

21. Calibration of near-bottom optical backscatterance sensor at channel marker 17, South San Francisco Bay, California, water year 1995

22. Time series of mid-depth suspended-solids concentration calculated from sensor readings at channel marker 17, South San Francisco Bay, California, water year 1995

23. Time series of near-bottom suspended-solids concentration calculated from sensor readings at channel marker 17, South San Francisco Bay, California, water year 1995

24. Calibration of mid-depth optical backscatterance sensor (with wiper) at Dumbarton Bridge, South San Francisco Bay, California, water year 1995

25. Calibration of near-bottom optical backscatterance sensor (with wiper) at Dumbarton Bridge, South San Francisco Bay, California, water year 1995

26. Time series of mid-depth suspended-solids concentration calculated from sensor readings at Dumbarton Bridge, South San Francisco Bay, California, water year 1995

27. Time series of near-bottom suspended-solids concentration calculated from sensor readings at Dumbarton Bridge, South San Francisco Bay, California, water year 1995

28. Calibration of mid-depth optical backscatterance sensor (with wiper) at San Mateo Bridge, South San Francisco Bay, California, water year 1995

29. Calibration of near-bottom optical backscatterance sensor (with wiper) at San Mateo Bridge, South San Francisco Bay, California, water year 1995

30. Time series of mid-depth suspended-solids concentration calculated from sensor readings at San Mateo Bridge, South San Francisco Bay, California, water year 1995

31. Time series of near-bottom suspended-solids concentration calculated from sensor readings at San Mateo Bridge, South San Francisco Bay, California, water year 1995

\section{TABLES}

1. Statistical summary of suspended-solids concentration data, Suisun Bay and Central and South San Francisco Bays, California, water year 1995 ...

2. Percentage of valid data collected by optical backscatterance sensors, Suisun Bay and Central and South San Francisco Bays, California, water year 1995 


\begin{tabular}{rcl}
\hline Multiply & By & To obtain \\
& & \\
\hline inch (in.) & 25.40 & millimeter \\
foot (ft) & 0.3048 & meter \\
foot per second (ft/s) & 0.3048 & meter per second \\
mile (mi) & 1.609 & kilometer \\
pound (lb) & 0.4536 & kilogram
\end{tabular}

Temperature is given in degrees Celsius ( $\mathrm{C}$ ), which can be converted to degrees Fahrenheit $\left({ }^{\circ} \mathrm{F}\right)$ by the following equation:

$$
{ }^{\circ} \mathrm{F}=1.8\left({ }^{\circ} \mathrm{C}\right)+32 \text {. }
$$

Sea level: In this report, "sea level" refers to the National Geodetic Vertical Datum of 1929-a geodetic datum derived from a general adjustment of the first-order level nets of the United States and Canada, formerly called Sea Level Datum of 1929.

Mean lower low water (MLLW): The average of the lower low water height of each tidal day observed over the National Tidal Datum Epoch. The National Tidal Datum Epoch is the specific 19-year period (1960-1978 for values given in this report) adopted by the National Ocean Service as the official time segment over which tide observations are taken and reduced to obtain mean values.

\begin{tabular}{cl}
\multicolumn{2}{c}{ ABBREVIATIONS } \\
${ }^{\circ} \mathrm{C}$ & degrees Celsius \\
$\mu \mathrm{m}$ & micrometer \\
$\mathrm{mg} / \mathrm{L}$ & milligram per liter
\end{tabular}

$\begin{aligned} & \text { ACRONYMS } \\ \text { AC } & \text { alternating current } \\ \text { ADAPS } & \text { automated data processing system } \\ \text { DC } & \text { direct current } \\ \text { DWR } & \text { California Department of Water Resources } \\ \text { mV } & \text { millivolt } \\ \text { NTU } & \text { Nephelometric Turbidity Units } \\ \text { PG\&E } & \text { Pacific Gas and Electric } \\ \text { PVC } & \text { polyvinyl chloride } \\ \text { USGS } & \text { U.S. Geological Survey }\end{aligned}$




\title{
Summary of Suspended-Solids Concentration Data, San Francisco Bay, California, Water Year 1995
}

\author{
By Paul A. Buchanan and David H. Schoellhamer
}

\begin{abstract}
Suspended-solids concentration data were collected in San Francisco Bay during water year 1995 (October 1, 1994-September 30, 1995). Optical backscatterance sensors and water samples were used to monitor suspended solids continuously at two sites in Suisun Bay, two sites in Central San Francisco Bay, and three sites in South San Francisco Bay. Sensors were positioned at two depths at each site. Water samples were collected periodically and were analyzed for concentrations of suspended solids. The results of the analyses were used to calibrate the electrical output of the optical backscatterance sensors. This report presents the data-collection methods used and summarizes the suspended-solids concentration data collected from October 1994 through September 1995. Calibration plots and edited data for each sensor also are presented.
\end{abstract}

\section{INTRODUCTION}

Sediments are an important component of the San Francisco Bay estuarine system. Potentially toxic substances, such as metals and pesticides, adsorb to sediment particles (Kuwabara and others, 1989; Domagalski and Kuivila, 1993). The sediments on the bay bottom provide the habitat for benthic communities that can ingest these substances and introduce them into the food web (Luoma and others, 1985; Brown and Luoma, 1995). Bottom sediments also are a reservoir of nutrients that contribute to the maintenance of estuarine productivity (Hammond and others, 1985). The transport and fate of suspended sediment are important factors in determining the transport and fate of constituents adsorbed on the sediment. In Suisun Bay, the maximum concentration of suspended solids usually marks the position of the turbidity maximum, which is a crucial ecological region in which suspended sediment, nutrients, phytoplankton, zooplankton, larvae, and juvenile fish accumulate (Peterson and others, 1975; Arthur and Ball, 1979; Kimmerer, 1992; Jassby and Powell, 1994). Suspended sediments also limit light availability in the bay, which, in turn, limits photosynthesis and primary phytosynthetic carbon production (Cloern, 1987; Cole and Cloern, 1987), and deposit in ports and shipping channels, which must be dredged to maintain navigation (U.S. Environmental Protection Agency, 1992). The U.S. Geological Survey (USGS), in cooperation with the San Francisco Regional Water Quality Control Board (Suisun Bay and South San Francisco Bay) and the U.S. Army Corps of Engineers (Central San Francisco Bay), is studying the factors that affect suspended-solids concentrations in San Francisco Bay. 


\section{Purpose and Scope}

This report summarizes suspended-solids concentration data collected by the USGS in San Francisco Bay in water year 1995 (October 1, 1994-September 30, 1995). Suspended-solids concentrations were monitored continuously at two sites in Suisun Bay, two sites in Central San Francisco Bay, and three sites in South San Francisco Bay.

Complete data for water year 1995 are available from the files of the USGS in Sacramento, California. Data collected in water years 1992 and 1993 are summarized in a report by Buchanan and Schoellhamer (1995) and data collected in water year 1994 are summarized in a report by Buchanan and others (1996). These data have been used by Tobin and others (1995) to study suspended-solids flux at Mallard Island in Suisun Bay, by Schoellhamer (1996) to study the factors that affect suspended-solids concentration in South San Francisco Bay and by Lacy and others (1996) to study suspended-solids flux in South San Francisco Bay.

\section{Study Area}

In San Francisco Bay (fig. 1), tides are semidiurnal with a range from about $5.5 \mathrm{ft}$ in Suisun Bay, to $6.5 \mathrm{ft}$ at the Golden Gate and Central San Francisco Bay (Central Bay), to about $10 \mathrm{ft}$ in South San Francisco Bay (South Bay). The tides also have a 14-day spring-neap cycle. Typical tidal currents range from $0.6 \mathrm{ft} / \mathrm{s}$ in shallow water to more than $3 \mathrm{ft} / \mathrm{s}$ in deep channels (Smith, 1987). Winds are typically strongest during the summer when there is an afternoon onshore sea breeze. Most precipitation occurs from late fall to early spring, and freshwater discharge into the bay is greatest in the winter due to runoff from storms. About 90 percent of the discharge is from the Sacramento-San Joaquin River Delta, which drains the Central Valley of California (Smith, 1987). Delta discharge contains 83 to 86 percent of the fluvial sediments that enter the bay (Porterfield, 1980) and determines the position of the turbidity maximum in Suisun Bay (Peterson and others, 1975; Arthur and Ball, 1979; Kimmerer, 1992; Jassby and Powell, 1994). During wet winters, turbid plumes of water from the delta have extended into South Bay (Carlson and McCulloch, 1974). The bottom sediments are composed of mostly silts and clays in South Bay and in the shallow waters (about $12 \mathrm{ft}$ or less) of Central and Suisun Bays. Silts and sands are present in the deeper parts of Central, San Pablo, and Suisun Bays and in Carquinez Strait (Conomos and Peterson, 1977). Large tidal velocities, spring tides, and wind waves in shallow water are all capable of resuspending bottom sediments (Powell and others, 1989; Schoellhamer, 1996).

\section{Acknowledgments}

The authors gratefully acknowledge the U.S. Coast Guard, California Department of Transportation, California Department of Water Resources (DWR), the San Francisco Port Authority, and the PakTank Corporation for their permission and assistance in establishing the monitoring sites used in this study. 


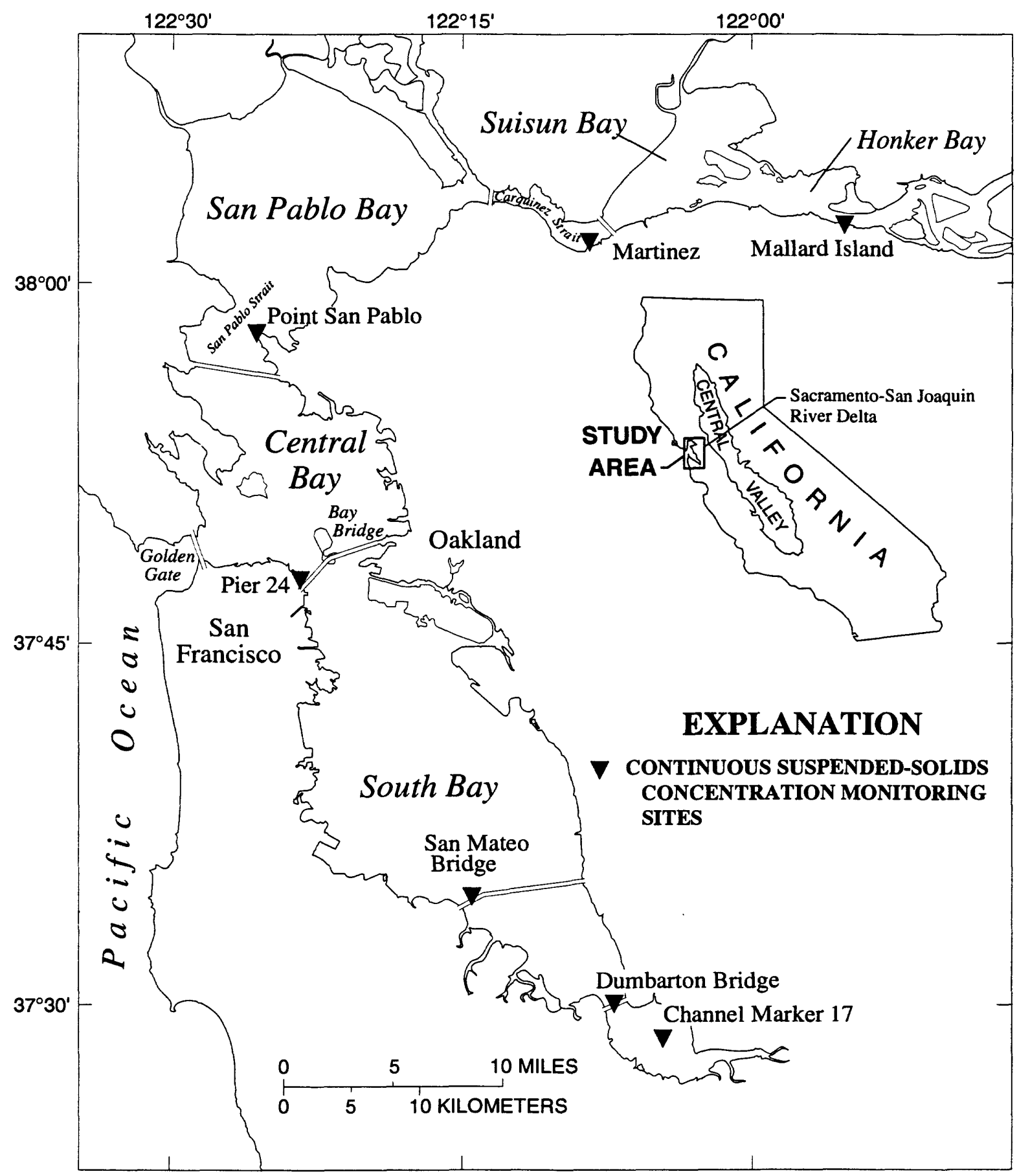

Figure 1. San Francisco Bay study area. 


\section{METHODS}

\section{Instrument Description and Operation}

Optical backscatterance sensors were used to monitor concentrations of suspended solids. An optical backscatterance sensor is a cylinder approximately $7 \mathrm{in}$. long and $1 \mathrm{in}$. in diameter with an optical window at one end, a cable connection at the other end, and an encased circuit board (Downing and others, 1981; Downing, 1983). An infrared pulse of light is transmitted through the optical window and is scattered or reflected by particles in front of the window to a distance of about 4 to $8 \mathrm{in}$. at angles up to 165 degrees. Some of this scattered or reflected light is returned to the optical window where a receiver converts the backscattered light to a voltage output. The voltage output is proportional to the concentration of suspended solids in the water column. Calibration of the sensor output to concentrations of suspended solids will vary depending on the size and optical properties of the suspended solids; therefore, the sensors must be calibrated either in the field or in a laboratory using the same suspended material that is found in the field (Levesque and Schoellhamer, 1995).

The optical sensors were positioned in the water column using polyvinyl chloride (PVC) pipe carriages that were coated with an antifoulant paint to impede biological growth. These carriages were designed to align with the direction of flow and to ride along a stainless-steel or Kevlar reinforced nylon suspension line attached to an anchor weight, which allowed the sensors to be raised and lowered easily for servicing. The plane of the optical window was positioned parallel to the direction of flow, and, as the carriage and sensor moved with the changing direction of flow, the plane of the window retained its position relative to the direction of flow.

Data acquisition, data storage, and sensor timing were controlled by an electronic data logger. The logger was programmed to power the optical sensors once every 15 minutes, collect data every second for 1 minute, and average and store the output voltages. Power was supplied by 12-volt DC, 12-amp-hour, gelcell batteries.

Biological growth interferes with the collection of accurate optical backscatterance data. Selfcleaning optical sensors with wipers were deployed at four sites in 1994 to help alleviate the problem of fouling. The wiper probes are similar in size and function to the optical sensors already in use, but the wiper probe has a separate electronics unit, which was used to set the full-scale optical backscatter, expressed in Nephelometric Turbidity Units (NTU). Output from the wiper probe is averaged over a 1 -minute period and is stored on a data logger every 15 minutes. Because the unit requires 95 to $130 \mathrm{AC}$, installation was limited to sites with $\mathrm{AC}$ power. The wiper probes and electronic units were installed at two sites in Suisun Bay and at two sites in South Bay. Fouling in Suisun Bay was light compared to that in South Bay, and the wiper probes were effective in keeping the optical ports clean (about 70-percent data recovery in water year 1995). However, fouling at the two sites in South Bay during the summer months was so extreme that the wiper probes were often rendered ineffective by biological growth on the carriage and wiper mechanism (about 35-percent recovery in water year 1995). During water year 1995, all wiper probes deployed in South Bay failed due to salt crystals forming on an O-ring, which resulted in leakage into the units.

Optical sensors without self-cleaning wipers required frequent cleaning, but, because of the difficulty in servicing some of the monitoring stations, cleaning was done every 1 to 5 (usually 3 ) weeks. Therefore, about 30 percent of the data collected was invalidated by fouling. Fouling generally was greatest on the sensor closest to the water surface. However, at shallower sites where the upper sensor was set $10 \mathrm{ft}$ above the lower sensor, fouling was about equal on both sensors. Fouling would begin to affect sensor output from 2 days to several weeks after cleaning, depending on the level of biological activity in the bay. Generally, biological fouling was greatest during the spring and summer months. 


\section{Suisun Bay Installations}

Suspended-solids concentration data were collected at two sites in Suisun Bay: Suisun Bay at Mallard Island and Carquinez Strait at Martinez (fig. 1). Monitoring equipment was installed at both sites in water year 1994.

\section{Mallard Island}

Self-cleaning optical sensors were installed at the DWR Mallard Island Compliance Monitoring Station on February 8, 1994 (lat. $38^{\circ} 02^{\prime} 34^{\prime \prime}$, long. $121^{\circ} 55^{\prime} 09^{\prime \prime}$ ). This site is about 5 mi downstream from the confluence of the Sacramento and San Joaquin Rivers and is at the north shore of Mallard Island near the eastern boundary of Honker Bay, an embayment of Suisun Bay (fig. 1). The station was constructed in the early 1980's by DWR on Pacific Gas and Electric (PG\&E) property, and, in January 1984, data were first recorded. A quarter-mile-long wooden walkway crosses the sometimes submerged reedbeds of Mallard Island and connects the concrete block house to the levee road.

Sensors were positioned at near-bottom ( $5 \mathrm{ft}$ above the bottom) and near-surface ( $3.3 \mathrm{ft}$ below the surface) to coincide with DWR near-bottom electrical conductance and temperature sensors and nearsurface pump intake. The pump intake is attached to a float housed inside a 12-in. PVC pipe and draws water from about $3 \mathrm{ft}$ below the surface. DWR near-surface parameters are measured by sensors submerged in flow-through chambers inside the gage house. This allows the USGS to use DWR data for parameters other than turbidity and saves the cost of installing duplicate sets of sensors. DWR also monitors stage, $\mathrm{pH}$, chlorophyll concentration, and meteorological parameters. Mean lower low water (MLLW) depth at this site is about $25 \mathrm{ft}$.

Data storage is controlled by a data logger connected to a cellular phone and modem. AC power is used to operate both optical sensors and to charge a 12-volt, 12-amp-hour battery that powers the data logger and modem. The instruments are housed inside the gage house. The sensors are suspended from a galvanized support stand attached to the metal railing on the northwest corner of the concrete deck of the station. This stand has two stainless-steel lines attached to separate concrete weights, one for the near-bottom sensor and the other for the near-surface sensor. The near-bottom sensor is positioned in a PVC carriage suspended on the stainless-steel line by a nylon rope at the specified depth. The near-surface sensor is housed in a PVC carriage that is attached to a float. This float assembly moves up and down the suspension line during tidal cycles, which maintains the near-surface sensor at the same depth as the DWR pump intake. A pressure transducer is positioned on the float assembly at the same level as the sensor and provides data to verify the depth of the near-surface sensor. To prevent sensor cables from being snagged by debris, a counterweight was installed to keep slack cables out of the water.

\section{Martinez}

Self-cleaning optical sensors were installed at the DWR Martinez Compliance Monitoring Station on February 8, 1994 (lat. $38^{\circ} 01^{\prime} 40^{\prime \prime}$, long. $122^{\circ} 08^{\prime} 22^{\prime \prime}$ ). This site is at the end of the Martinez Marina fishing pier at the south shore of the Carquinez Strait where it widens into Suisun Bay (fig. 1). The station was constructed in the early 1980's by DWR on City of Martinez property, and, in May 1983, data were first recorded.

Sensors were positioned at near-bottom ( $5 \mathrm{ft}$ above the bottom) and near-surface $(3.3 \mathrm{ft}$ below the surface) to coincide with placement of DWR sensors. Data from the near-bottom sensor are representative of local circulation patterns and a nearby mudflat. During floodtides, output from the near-bottom sensor was poorly correlated with independent optical sensor measurements made slightly north of the site (Tobin and others, 1995). The near-bottom sensor was removed on December 2, 1994. Mean lower low water depth at this site is about $31 \mathrm{ft}$. Data storage, power supplies, and installation descriptions are identical to those for the Mallard Island station with the exception that Martinez does not have a cellular phone or modem and the shelter and deck are wood structures. 


\section{Central San Francisco Bay Installations}

Suspended-solids concentration data were collected at two sites in Central San Francisco Bay beginning in water year 1993: San Pablo Strait at Point San Pablo and Pier 24 at San Francisco (fig. 1).

\section{Point San Pablo}

The USGS maintains a monitoring station at San Pablo Strait on the northern end of the Richmond Terminal no. 4 pier (lat. $37^{\circ} 57^{\prime} 53^{\prime \prime}$, long. $122^{\circ} 25^{\prime} 42^{\prime \prime}$ ) on the western side of Point San Pablo (fig. 1). The USGS took over operation of this station in October 1989 from the DWR. Data collected prior to October 1, 1989, can be obtained from DWR.

Optical sensors were installed at Point San Pablo on December 1, 1992, and were positioned at nearbottom and mid-depth ( $3 \mathrm{ft}$ and $13 \mathrm{ft}$ from the bottom). Mean lower low water depth at this site is about $26 \mathrm{ft}$. Specific electrical conductance and temperature data (cooperatively funded with DWR) are collected at near-surface and near-bottom points in the water column. Sensor timing and storage are controlled by a data logger connected to a phone line and modem. Water level is recorded using a float-driven, incremental encoder wired into the data logger, and outside water levels are read using a wire-weight gage. A separate data logger controls the optical sensors. AC power is available at this site and is used to charge a 12-volt, 60 -amp-hour battery that powers the data loggers and sensors. The instruments are housed in a 5 - by 8 - $\mathrm{ft}$ wooden shelter.

\section{Pier 24}

The monitoring station at Pier 24 is on the western end of the San Francisco-Oakland Bay Bridge (lat. $37^{\circ} 47^{\prime} 27^{\prime \prime}$, long. $122^{\circ} 23^{\prime} 05^{\prime \prime}$ ) (fig. 1). The USGS took over operation of this station from DWR in October 1989. Data collected prior to October 1, 1989, can be obtained from DWR.

Optical sensors were installed at the Pier 24 site on May 25, 1993, and were positioned at near-bottom and mid-depth ( $3 \mathrm{ft}$ and $23 \mathrm{ft}$ above the bottom). Mean lower low water depth at this site is about $41 \mathrm{ft}$. As at the Point San Pablo site, specific electrical conductance and temperature data (cooperatively funded with DWR) are collected at near-surface and near-bottom points in the water column. Sensor timing and storage are controlled by a data logger connected to a cellular phone and modem. AC power is available at this site and is used to charge a 12-volt, 12-amp-hour battery that powers the instrumentation. A corrugated steel shelter houses the equipment.

\section{South San Francisco Bay Installations}

Suspended-solids concentration data were collected at three sites in South San Francisco Bay (fig. 1). Monitoring stations were installed in water year 1992 at two sites, South San Francisco Bay at channel marker 17 and South San Francisco Bay at San Mateo Bridge. The South San Francisco Bay at Dumbarton Bridge monitoring station was installed in water year 1993.

\section{Channel Marker 17}

The southernmost monitoring site in South Bay is at Coast Guard channel marker 17 (lat. $37^{\circ} 28^{\prime} 44^{\prime \prime}$, long. $122^{\circ} 04^{\prime} 38^{\prime \prime}$ ) (fig. 1). Instrumentation was installed on February 26, 1992, and the optical sensors were positioned at near-bottom and mid-depth ( $3 \mathrm{ft}$ and $13 \mathrm{ft}$ from the bottom). The mean lower low water depth at this site is about $25 \mathrm{ft}$. Sensor cables are protected by a 10-ft length of PVC pipe strapped to the channel marker support column. Sensor cables, carriages, and probes are suspended in the water column using a 100 -lb weight attached to a 1/4-in. Kevlar reinforced nylon line. The data logger and DC power are housed in a 2- by 2 - by 1-ft weather-proof enclosure mounted on the channel marker platform. 


\section{Dumbarton Bridge}

Suspended-solids concentration monitoring equipment was installed October 21, 1992, at Pier 23 of the Dumbarton Bridge on the west side of the ship channel (lat. $37^{\circ} 30^{\prime} 15^{\prime \prime}$, long. $122^{\circ} 07^{\prime} 10^{\prime \prime}$ ) (fig. 1). Optical sensors were deployed at near-bottom and mid-depth ( $3 \mathrm{ft}$ and $23 \mathrm{ft}$ above the bottom). Mean lower low water depth is about $45 \mathrm{ft}$. The sensors are suspended between the concrete pier superstructure and the fender boards, which are approximately $3 \mathrm{ft}$ apart. PVC carriages, attached to 1/4-in. Kevlar reinforced nylon line, are anchored to a 100-lb weight and are used to suspend the sensors at the desired depth.

The wiper probes in operation since March 17, 1994, both failed during water year 1995. The inoperable equipment was removed on July 26,1995 , and replacement sensors without the self-cleaning function were installed on October 12, 1995. The instruments are housed in a 3-by 2-by 1-ft weather-proof shelter mounted on the pier. AC power supplies the instruments.

\section{San Mateo Bridge}

The monitoring station on the San Mateo Bridge is at Pier 20 on the east side of the ship channel (lat. $37^{\circ} 35^{\prime} 04^{\prime \prime}$, long. $122^{\circ} 14^{\prime} 59^{\prime \prime}$ ) (fig. 1). This station originally was operated by DWR, but the USGS took over operations on October 1, 1989.

The optical sensors were installed on December 23, 1991, and were positioned at near-bottom and mid-depth ( $3 \mathrm{ft}$ and $23 \mathrm{ft}$ above the bottom). Mean lower low water depth at this site is about $48 \mathrm{ft}$. The instruments are housed in a wooden shelter on the pier, which is surrounded by a protective fender structure. The sensors are deployed between the pier and the fender, and flow past the sensors is affected to some degree by the pilings and the concrete superstructure. Sensors are suspended in place using PVC carriages and stainless-steel line attached to a 200-lb weight. A separate data logger and modem are used to control sensor timing, data storage, and retrieval. AC power is available at this site, and all instruments are powered by a 12-volt, 60 -amp-hour battery with an AC/DC charger and regulator. In addition to suspended-solids concentrations, specific electrical conductivity and temperature (cooperatively funded with DWR) are monitored at near-surface and near-bottom depths.

The wiper probes in operation since March 17, 1994, failed during the last quarter of water year 1994 and were replaced with new wiper probes on October 6, 1994. The near-bottom sensor failed immediately after deployment, and a replacement sensor installed on November 1, 1994, failed in April 1995. The middepth sensor failed in June 1995, and a replacement sensor installed on July 27, 1995, failed in August 1995. Sensors without the self-cleaning function were reinstalled on November 22, 1995.

\section{Water-Sample Collection}

Water samples were collected with a Van Dorn sampler before and after the sensors were cleaned. The Van Dorn sampler is a plastic tube with rubber stoppers at each end that snap shut when triggered by a small weight dropped down a suspension cable. The suspended-solids concentration of water samples collected with a Van Dorn sampler and a P-72 point sampler were compared and found to be virtually identical (Buchanan and others, 1996). With the optical sensors deployed, the sampler was lowered to the depth of the sensor by a reel and crane assembly and triggered while the sensor was collecting data. The sample was then removed from the sampler, marked for identification, and placed in a cooler and chilled to limit biological growth.

Samples were sent to the USGS Sediment Laboratory in Salinas, California, for analysis to determine suspended-solids concentration. Each sample was mixed well and a suitable volume was quickly poured into a graduated cylinder. The suspended solids were collected on a $0.45-\mu \mathrm{m}$ membrane filter, the filter was rinsed to remove salts, and the insoluble material was dried at $103^{\circ} \mathrm{C}$ and weighed (Fishman and Friedman, 1989). 


\section{Data Processing}

Data loggers stored the voltage outputs from the optical sensors every 15 minutes. Recorded data were downloaded from the data logger onto a storage module during site visits by USGS personnel. Raw data from the storage modules were loaded into the USGS's automated data processing system (ADAPS).

The time-series data were retrieved and visually edited to remove invalid data. Invalid data included rapidly increasing voltage outputs and unusually high voltage outputs of short duration. As biological growth occurred on the optical sensors, the voltage output of the sensors increased rapidly. An example time series of raw and edited data from water year 1994 is presented in figure 2 . After the sensors were cleaned, sensor output decreased discontinuously (fig. 2, April 19, June 8, and June 28). Efforts to correct the invalid data proved to be unsuccessful because the desired signal was sometimes highly variable. Thus, data collected during the period prior to sensor cleaning often were unusable and were removed from the record (fig. 2). Spikes in the data, which are anomalously high voltages probably caused by debris temporarily wrapping around the sensor or by large marine organisms (fish, crabs) on or near the sensor, also were removed from the raw data record (fig. 2). Sometimes incomplete cleaning of a sensor would cause a small constant shift in sensor output that could be corrected with water-sample data.
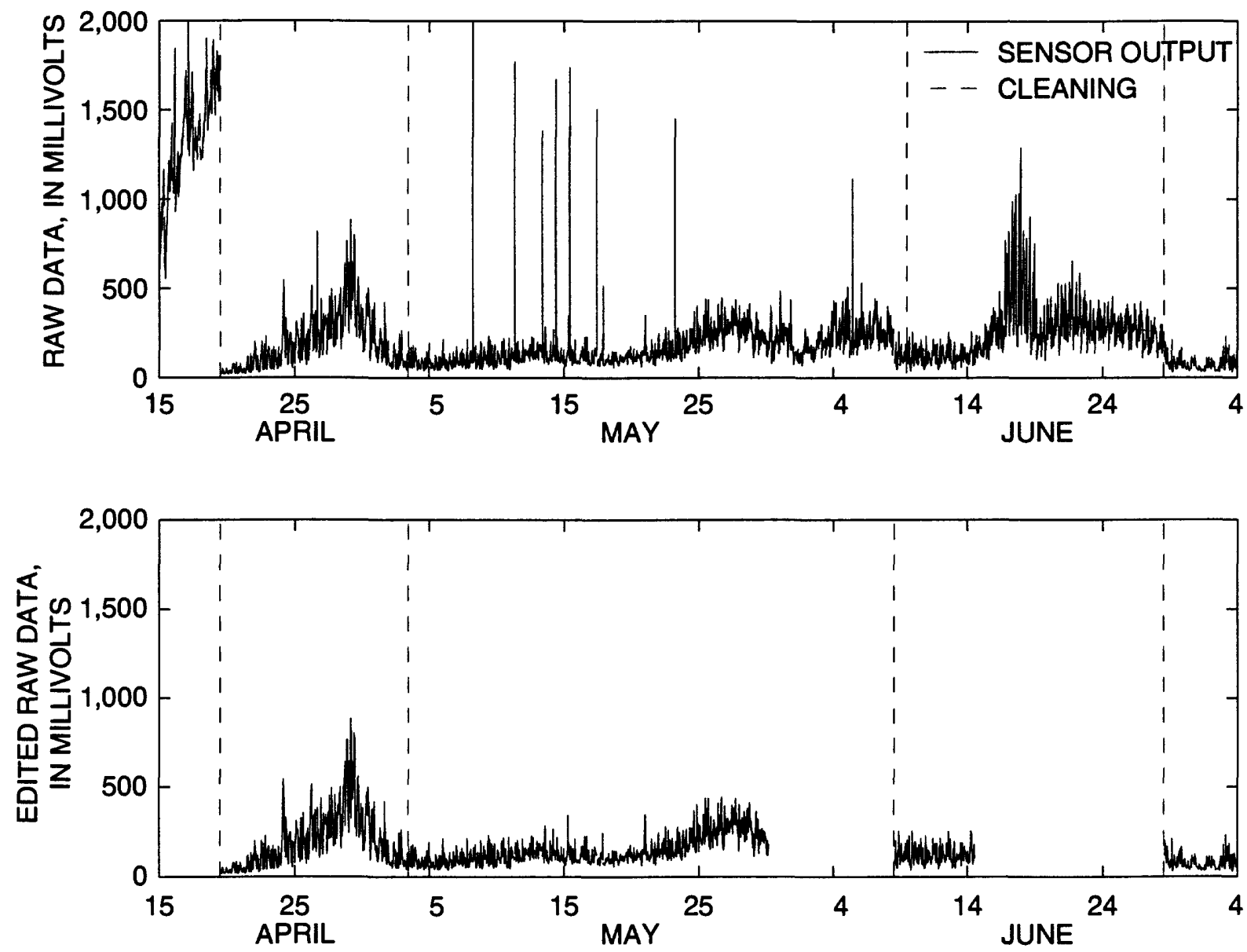

Figure 2. Raw and edited optical backscatterance data, mid-depth sensor, Point San Pablo, Central San Francisco Bay, California, water year 1994 (from Buchanan and others, 1996). 


\section{SENSOR CALIBRATION AND SUSPENDED-SOLIDS CONCENTRATION DATA}

Linear regression was used to calibrate sensor output to suspended-solids concentration. The calibration figures, time-series plots of suspended-solids concentration data, statistical summary table (table 1), and a table showing the percentage of valid data collected at each site (table 2) are presented. Calibration figures include the number of samples, correlation coefficient, squared correlation coefficient, regression significance level, and root-mean-squared error.

Table 1. Statistical summary of suspended-solids concentration data, Suisun Bay and Central and South San Francisco Bays, California, water year 1995

[All measurements are in milligrams per liter]

\begin{tabular}{llcccc}
\hline \multicolumn{1}{c}{ Site } & \multicolumn{1}{c}{ Depth } & Mean & Median & $\begin{array}{c}\text { Lower } \\
\text { quartile }\end{array}$ & $\begin{array}{c}\text { Upper } \\
\text { quartile }\end{array}$ \\
\hline Mallard Island & Near-surface & 43 & 32 & 27 & 41 \\
Martinez & Near-bottom & 41 & 33 & 27 & 43 \\
Point San Pablo & Near-surface & 68 & 52 & 37 & 77 \\
& Mid-depth & 58 & 45 & 30 & 68 \\
Pier 24 & Near-bottom & 91 & 66 & 42 & 110 \\
& Mid-depth & 41 & 36 & 20 & 53 \\
Channel marker 17 & Near-bottom & 84 & 56 & 30 & 110 \\
& Mid-depth & 120 & 92 & 57 & 160 \\
Dumbarton Bridge & Near-bottom & 190 & 130 & 65 & 240 \\
& Mid-depth & 98 & 63 & 42 & 110 \\
San Mateo Bridge & Near-bottom & 140 & 98 & 65 & 150 \\
& Mid-depth & 44 & 35 & 27 & 48 \\
& Near-bottom & 47 & 40 & 30 & 53 \\
\hline
\end{tabular}

Table 2. Percentage of valid data collected by optical backscatterance sensors, Suisun Bay and Central and South San Francisco Bays, California, water year 1995

\begin{tabular}{lll}
\hline \multicolumn{1}{c}{ Site } & \multicolumn{1}{c}{ Depth } & $\begin{array}{c}\text { Percent } \\
\text { valid data }\end{array}$ \\
\hline Mallard Island & Near-surface & 54 \\
& Near-bottom & 83 \\
Martinez & Near-surface & 67 \\
Point San Pablo & Mid-depth & 78 \\
& Near-bottom & 83 \\
Pier 24 & Mid-depth & 45 \\
& Near-bottom & 72 \\
Channel marker 17 & Mid-depth & 74 \\
& Near-bottom & 63 \\
Dumbarton Bridge & Mid-depth & 24 \\
& Near-bottom & 56 \\
San Mateo Bridge & Mid-depth & 41 \\
& Near-bottom & 26 \\
\hline
\end{tabular}




\section{Suisun Bay}

\section{Mallard Island}

The calibration of the near-surface sensor shifted from October 1, 1994, to December 2, 1994, and caused some clipping of lower concentration data. The water year 1994 calibration (Buchanan and others, 1996, fig. 4) was used for this period. The near-surface sensor was replaced on December 2, 1994. The calibration of the near-surface sensor had a standard error of $2.0 \mathrm{mg} / \mathrm{L}$ (fig. 3) and calibration of the nearbottom sensor had a standard error of $4.5 \mathrm{mg} / \mathrm{L}$ (fig. 5). Flood waters caused a small shift in the calibration of both the near-surface and near-bottom sensors from January 12 to March 31, 1995 (figs. 4 and 6). Suspended-solids concentration data collected during water year 1995 are presented in figures 7 and 8. There were several power failures during the water year resulting in lost data. In early September 1995, vandals stole the wires supplying power to the instrument shelter causing a lengthy loss of data that extended into water year 1996.

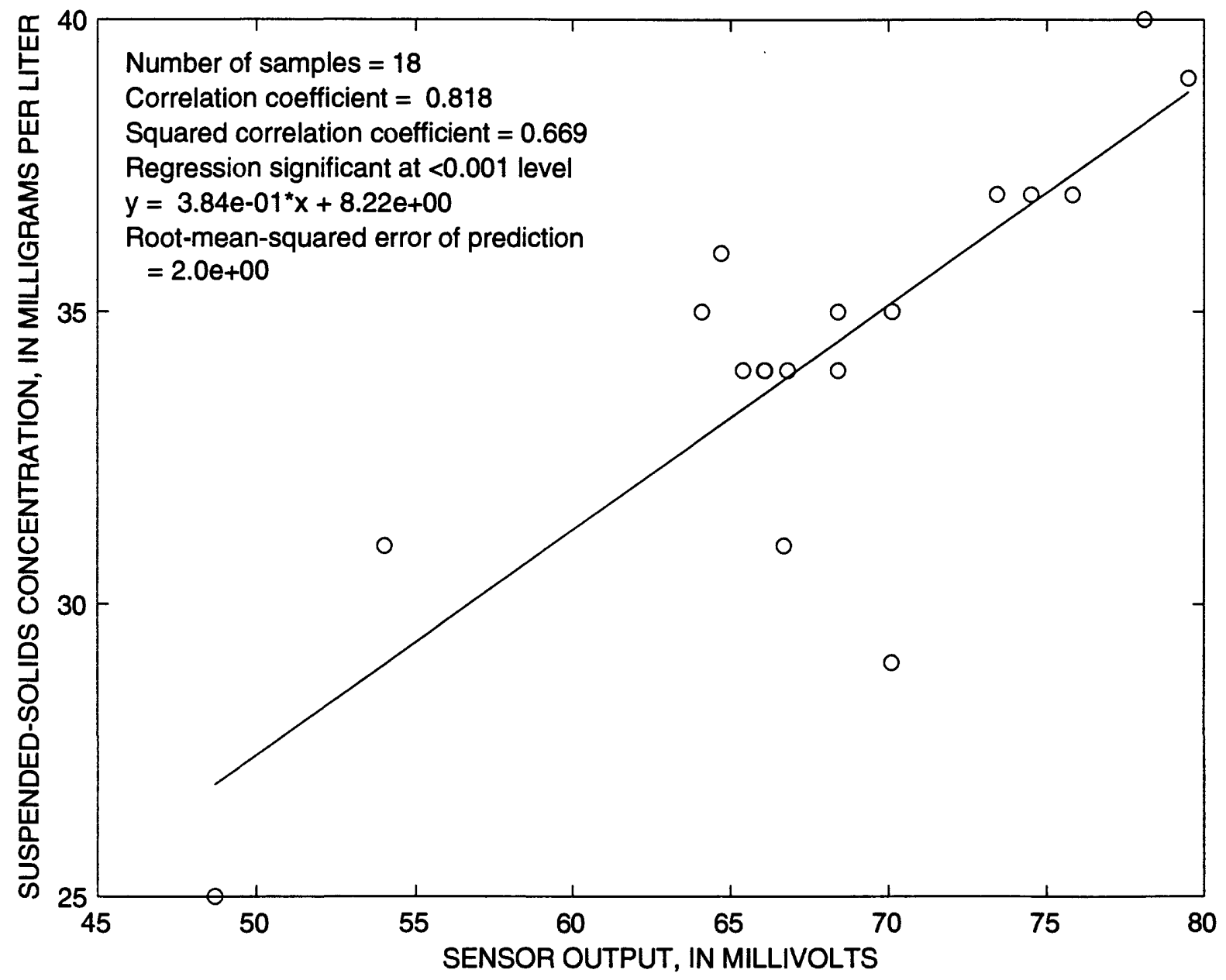

Figure 3. Calibration of near-surface optical backscatterance sensor (with wiper) at Mallard Island, Suisun Bay, California, water year 1995. 


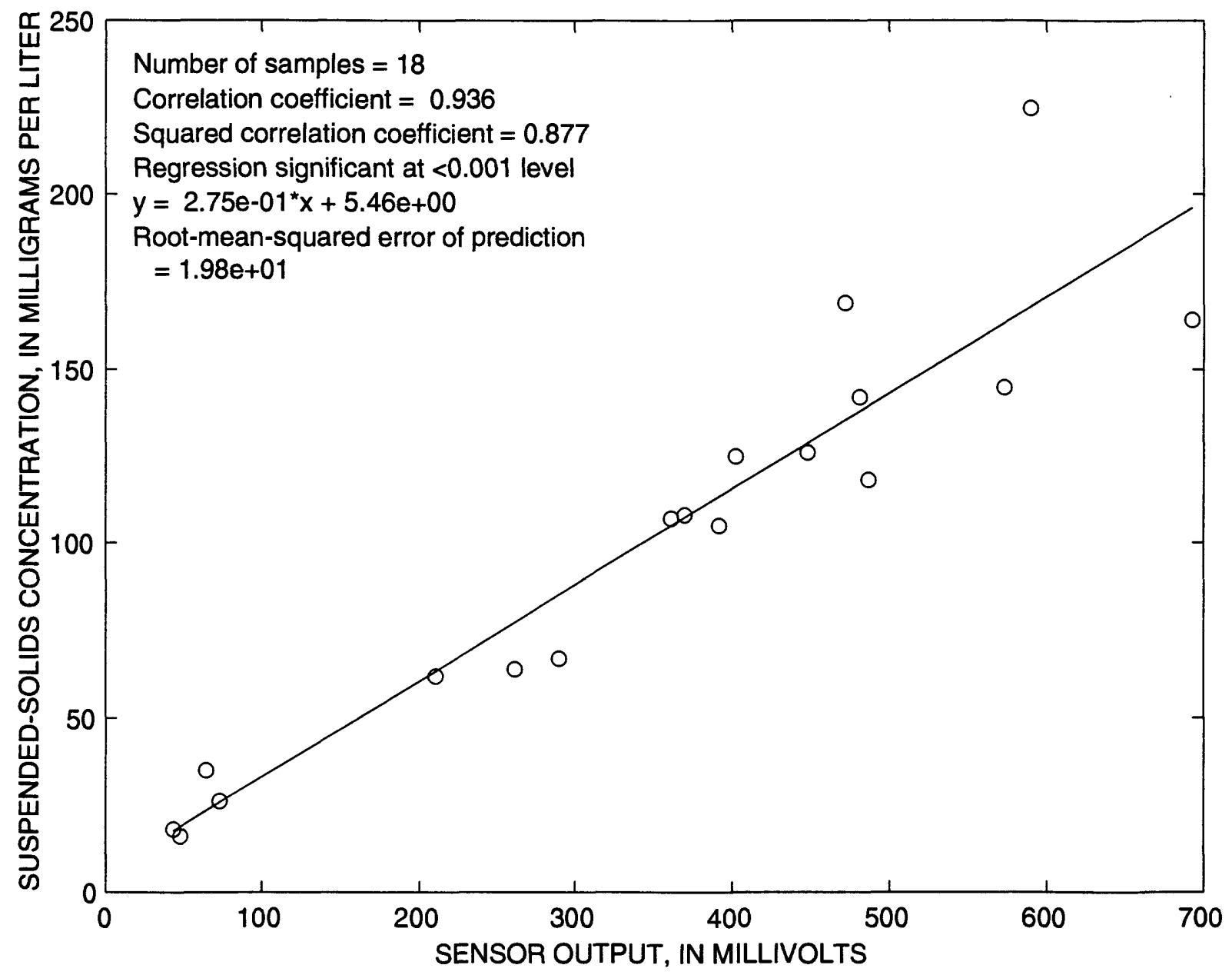

Figure 4. Calibration of near-surface optical backscatterance sensor (with wiper) during flood at Mallard Island, Suisun Bay, California, water year 1995. 


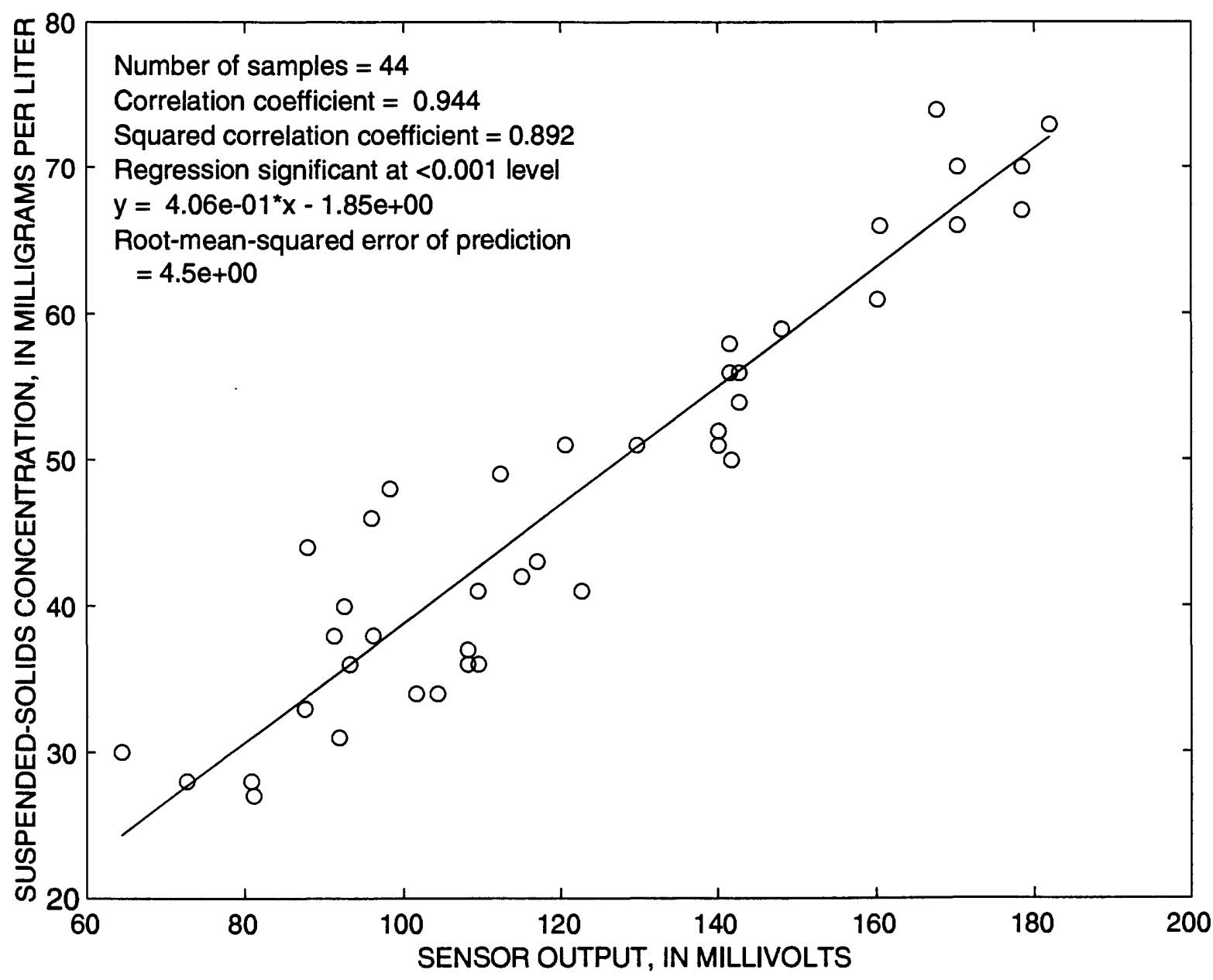

Figure 5. Calibration of near-bottom optical backscatterance sensor (with wiper) at Mallard Island, Suisun Bay, California, water year 1995. 


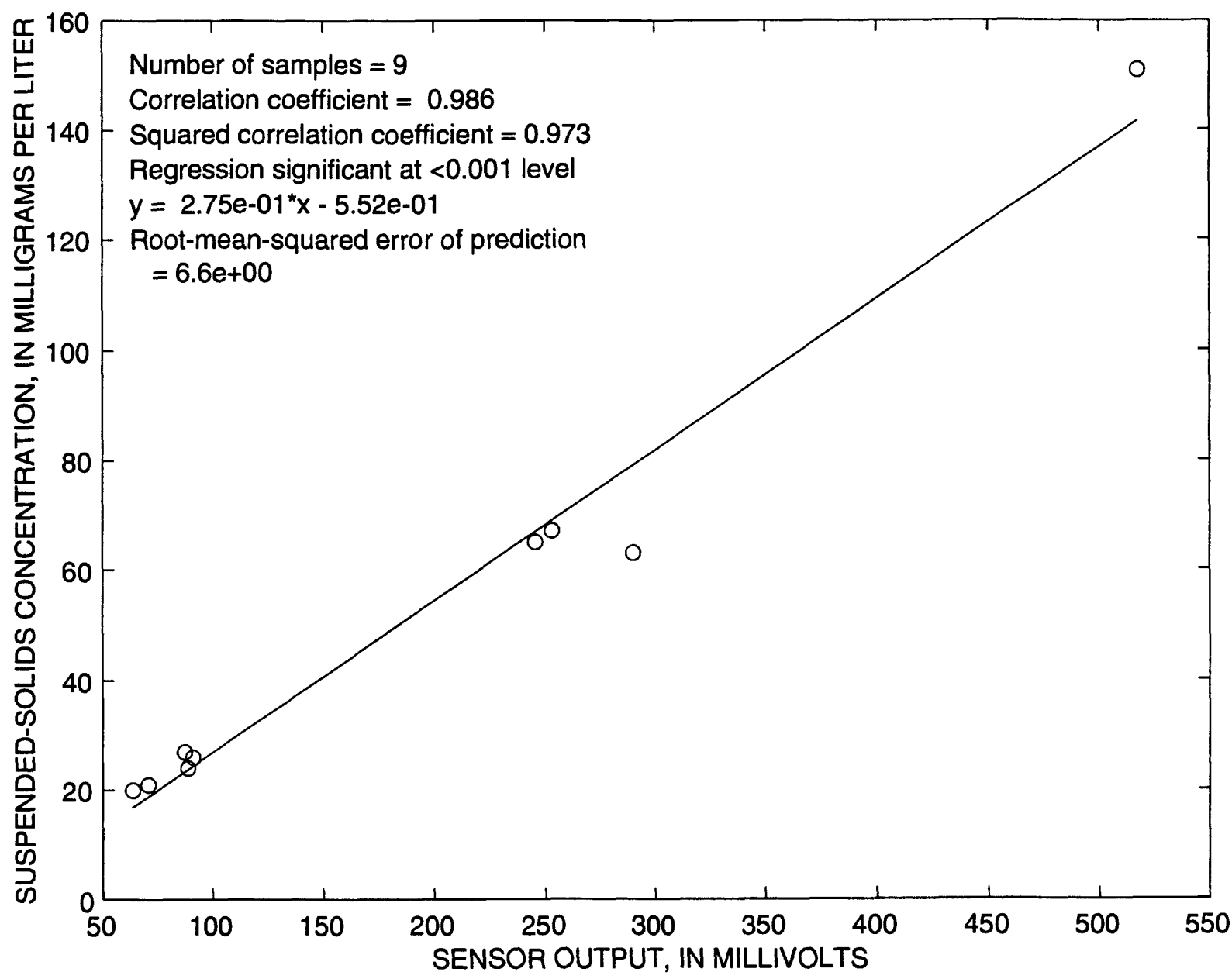

Figure 6. Calibration of near-bottom optical backscatterance sensor (with wiper) during flood at Mallard Island, Suisun Bay, California, water year 1995. 


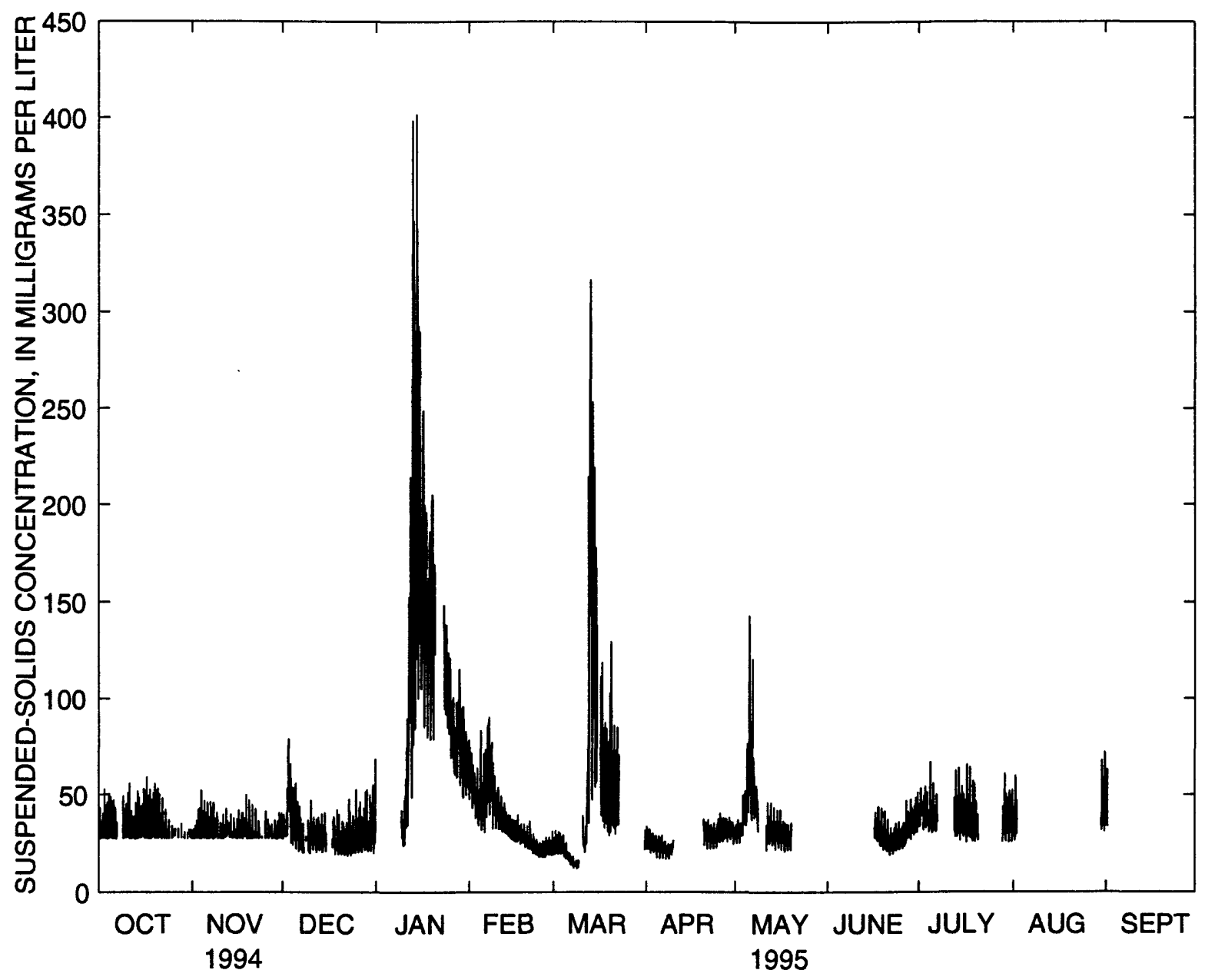

Figure 7. Time series of near-surface suspended-solids concentration calculated from sensor readings at Mallard Island, Suisun Bay, California, water year 1995. 


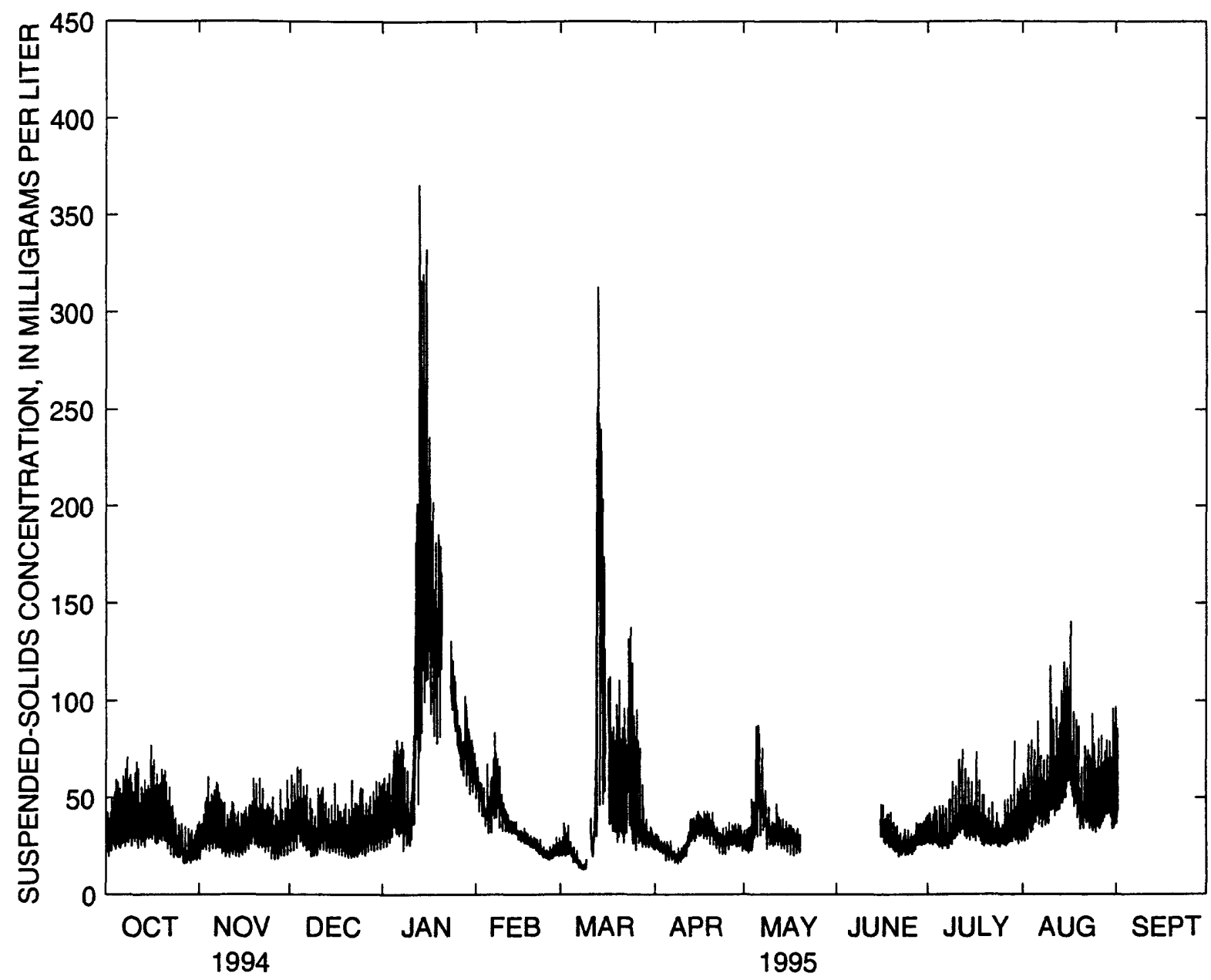

Figure 8. Time series of near-bottom suspended-solids concentration calculated from sensor readings at Mallard Island, Suisun Bay, California, water year 1995. 


\section{Martinez}

Calibration of the near-surface sensor at Martinez had a standard error of $9.4 \mathrm{mg} / \mathrm{L}$ (fig. 9). Flood waters caused a small shift in the calibration of the near-surface sensor from January 13 to March 31, 1995 (fig. 10). Incomplete cleaning of the sensor on May 11 probably caused a sensor output shift of $+57 \mathrm{mV}$ through May 22, 1995, which was corrected. The near-surface sensor was not deployed from October 21 to November 18, 1994, because of pier repairs. Suspended-solids concentration data collected during water year 1995 are presented in figure 11.

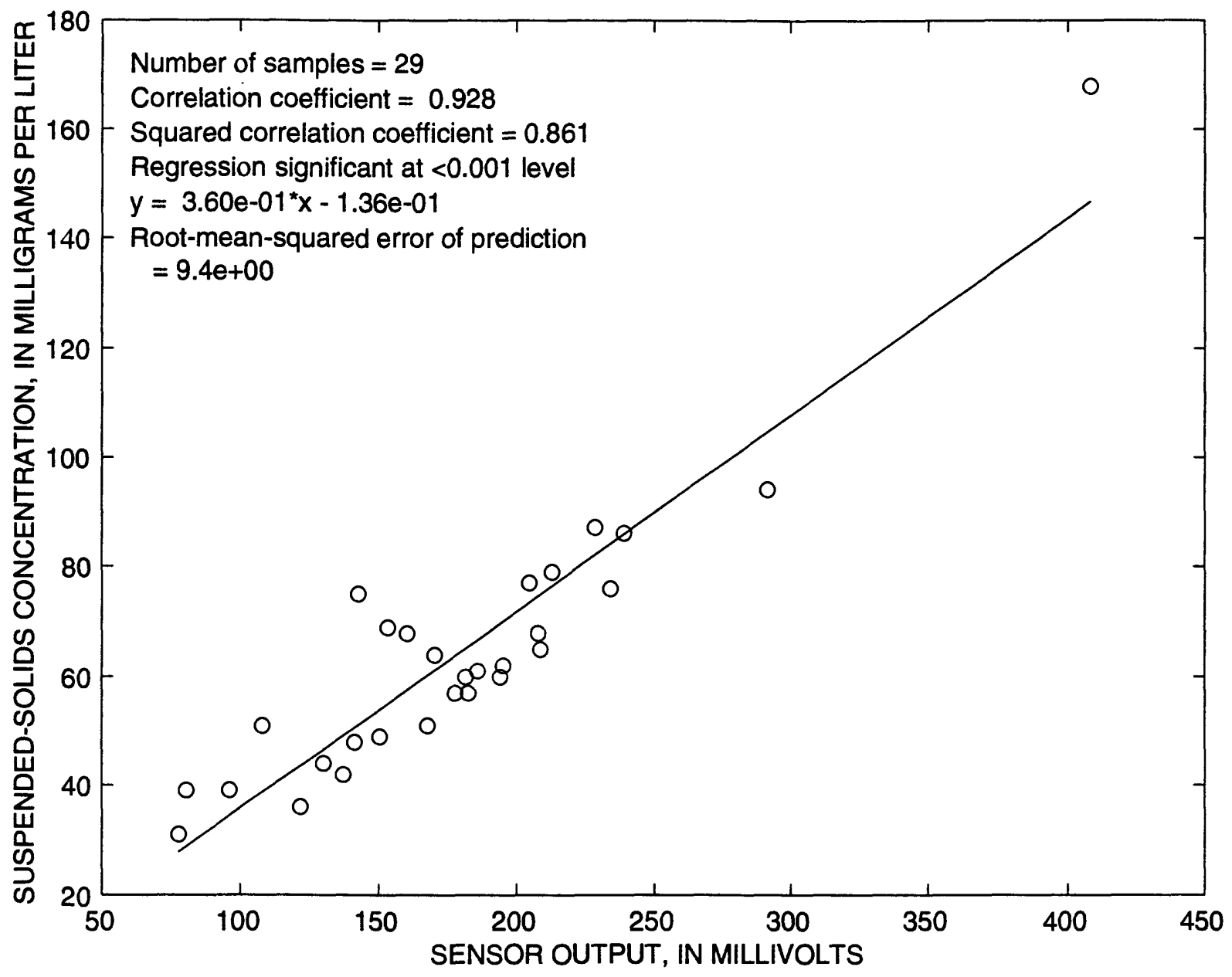

Figure 9. Calibration of near-surface optical backscatterance sensor (with wiper) at Martinez, Suisun Bay, California, water year 1995. 


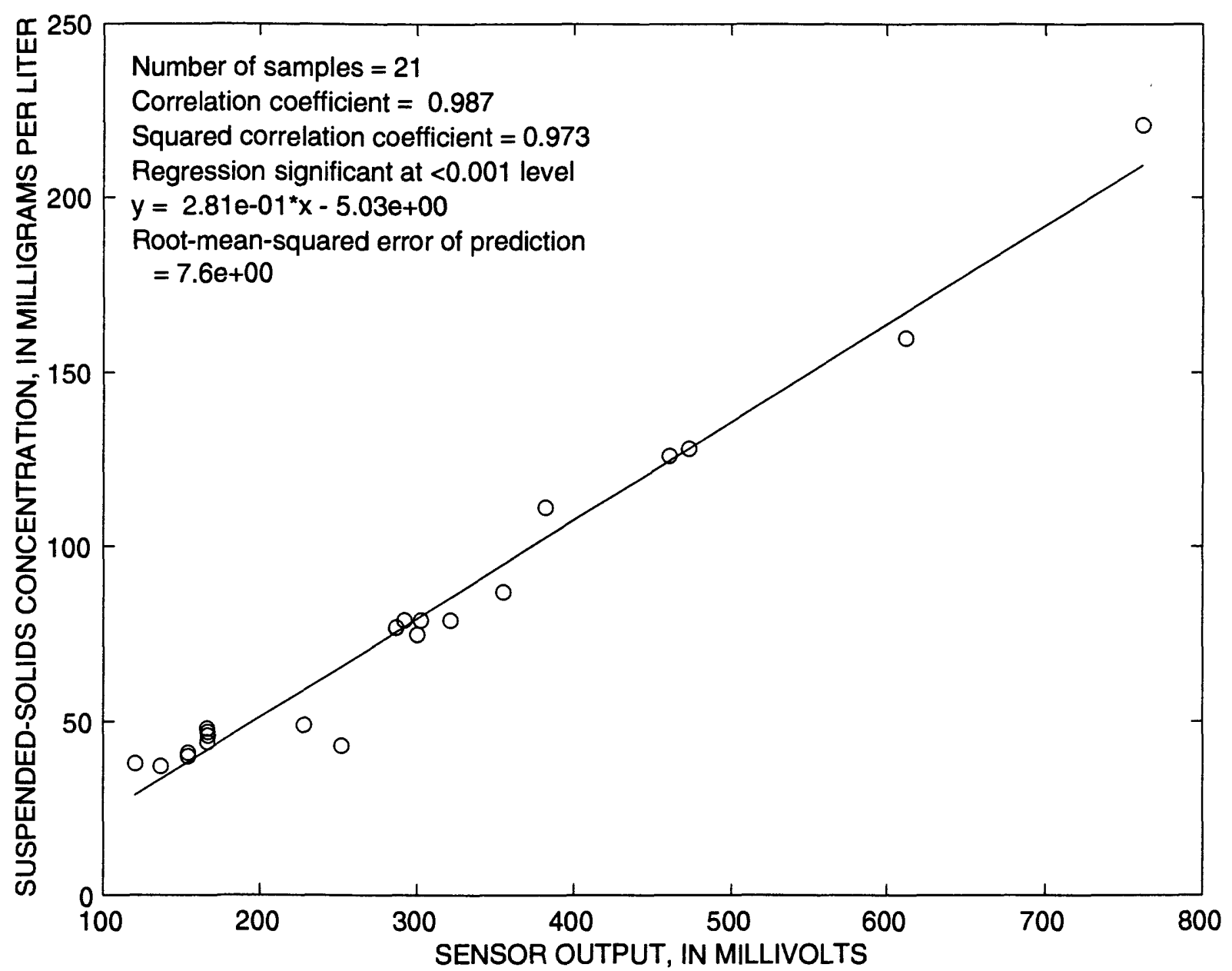

Figure 10. Calibration of near-surface optical backscatterance sensor (with wiper) during flood at Martinez, Suisun Bay, California, water year 1995. 


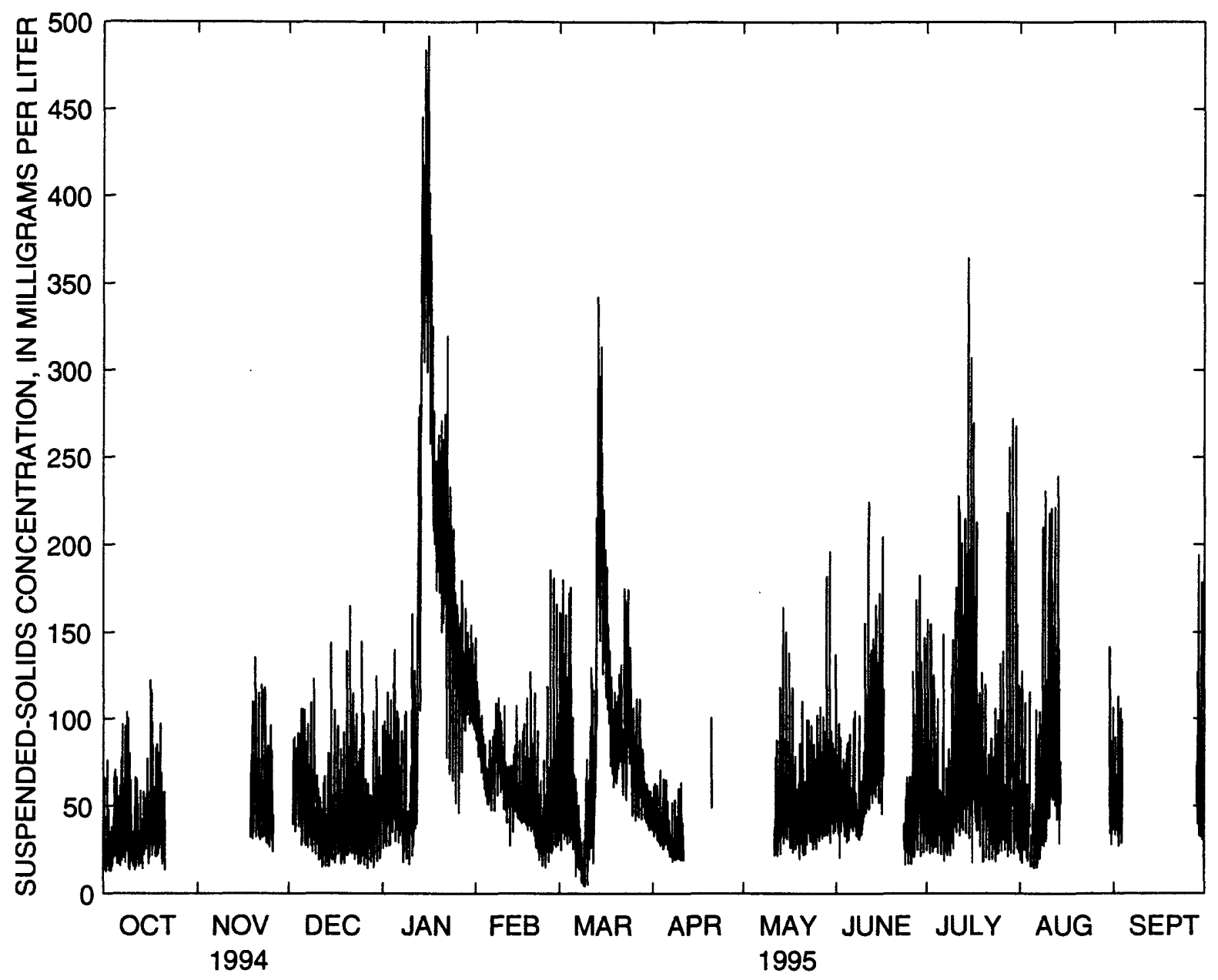

Figure 11. Time series of near-surface suspended-solids concentration calculated from sensor readings at Martinez, Suisun Bay, California, water year 1995. 


\section{Central San Francisco Bay}

\section{Point San Pablo}

Calibration of the mid-depth sensor shifted in September 1994. The calibration used in water year 1995 was developed using 1 sample from September 1994 and 30 samples from water year 1995 and had a standard error of $16 \mathrm{mg} / \mathrm{L}$ (fig. 12). A shift in the mid-depth sensor output occurred after cleaning on July 10, 1995, and lasted through August, but a reasonable correction based on water samples could not be determined, so no correction was applied. The calibration of the near-bottom sensor is based on samples collected in water year 1995 only and had a standard error of $27 \mathrm{mg} / \mathrm{L}$ (fig. 13). Comparisons with previous calibrations indicated that the slope of the calibration curve has decreased slightly with time. This was especially evident with the high concentration samples collected during winter 1993 and winter 1995 when runoff was large. A shift in the near-bottom sensor output occurred after cleaning on August 15, 1995, and lasted through August, but a reasonable correction based on water-sample data could not be determined, so no correction was applied. Suspended-solids concentration data collected during water year 1995 are presented in figures 14 and 15.

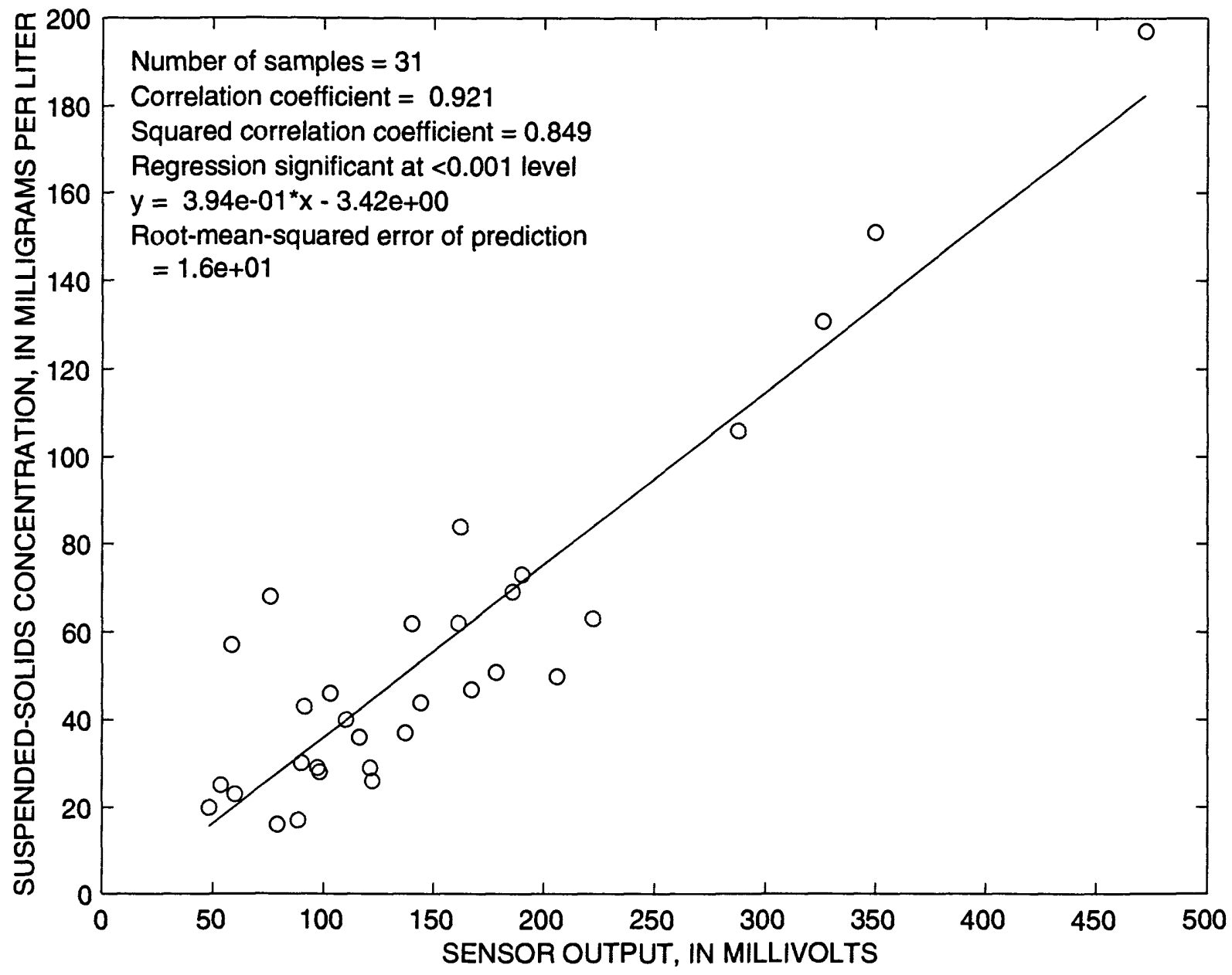

Figure 12. Calibration of mid-depth optical backscatterance sensor at Point San Pablo, Central San Francisco Bay, California, water year 1995. 


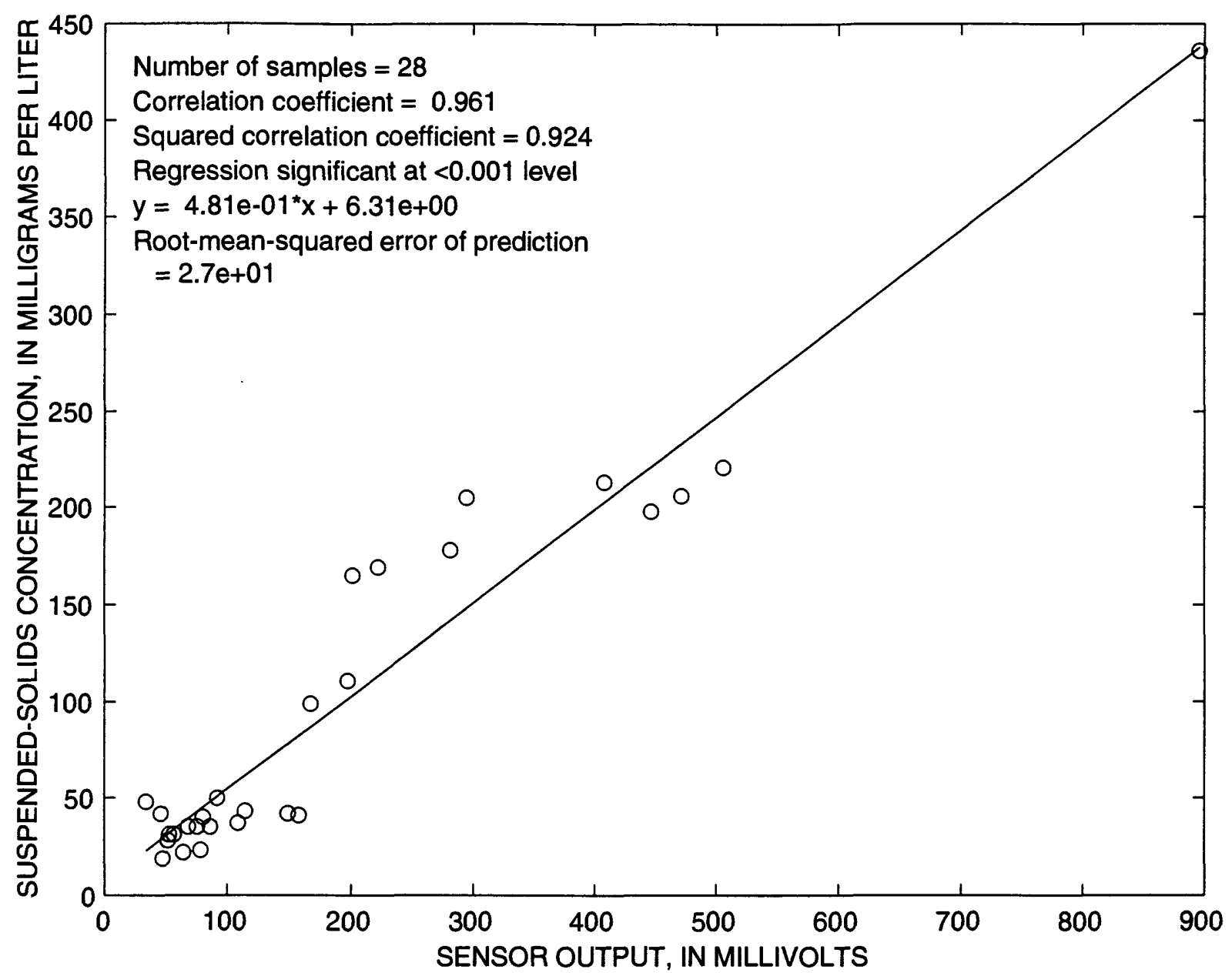

Figure 13. Calibration of near-bottom optical backscatterance sensor at Point San Pablo, Central San Francisco Bay, California, water year 1995. 


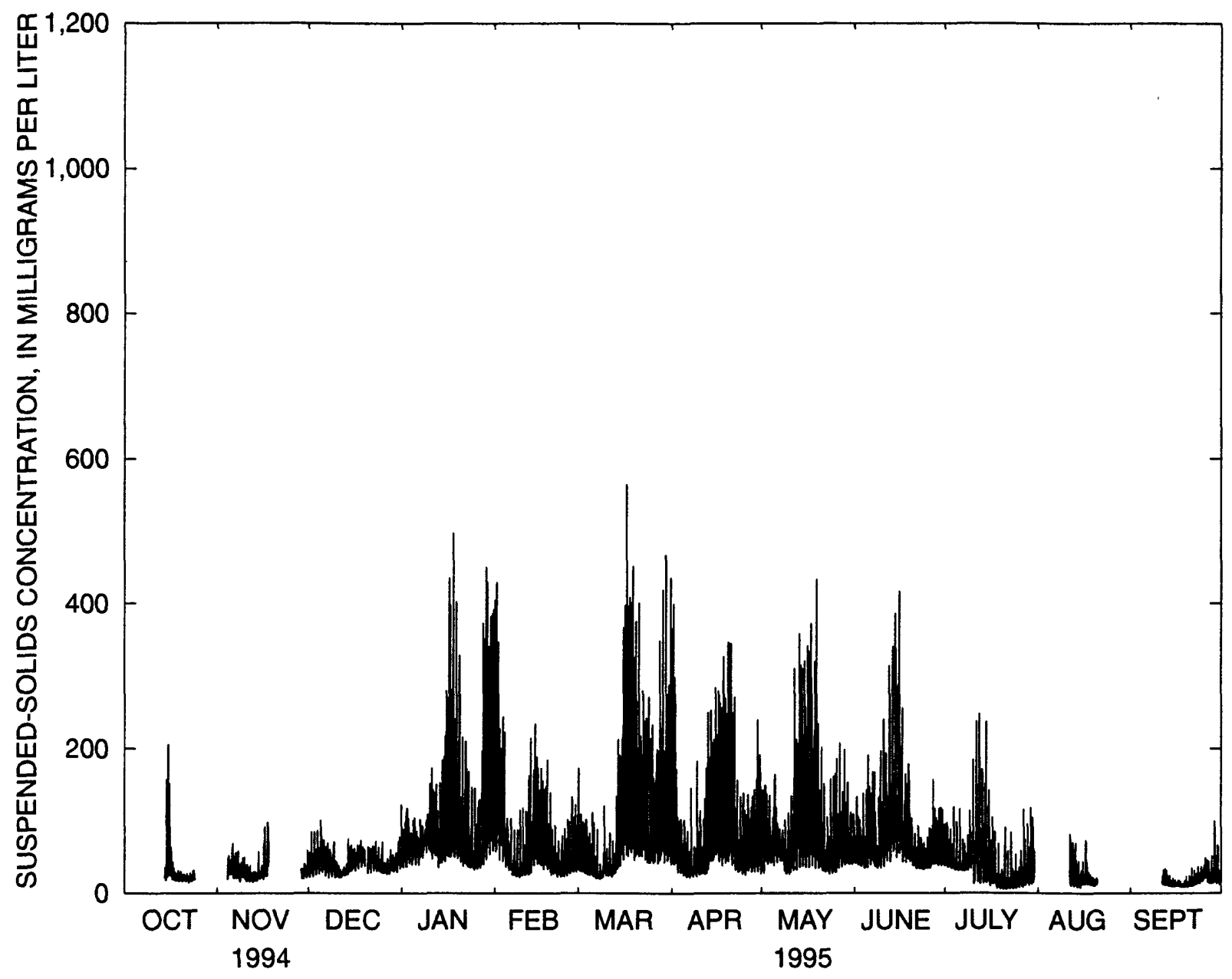

Figure 14. Time series of mid-depth suspended-solids concentration calculated from sensor readings at Point San Pablo, Central San Francisco Bay, California, water year 1995. 


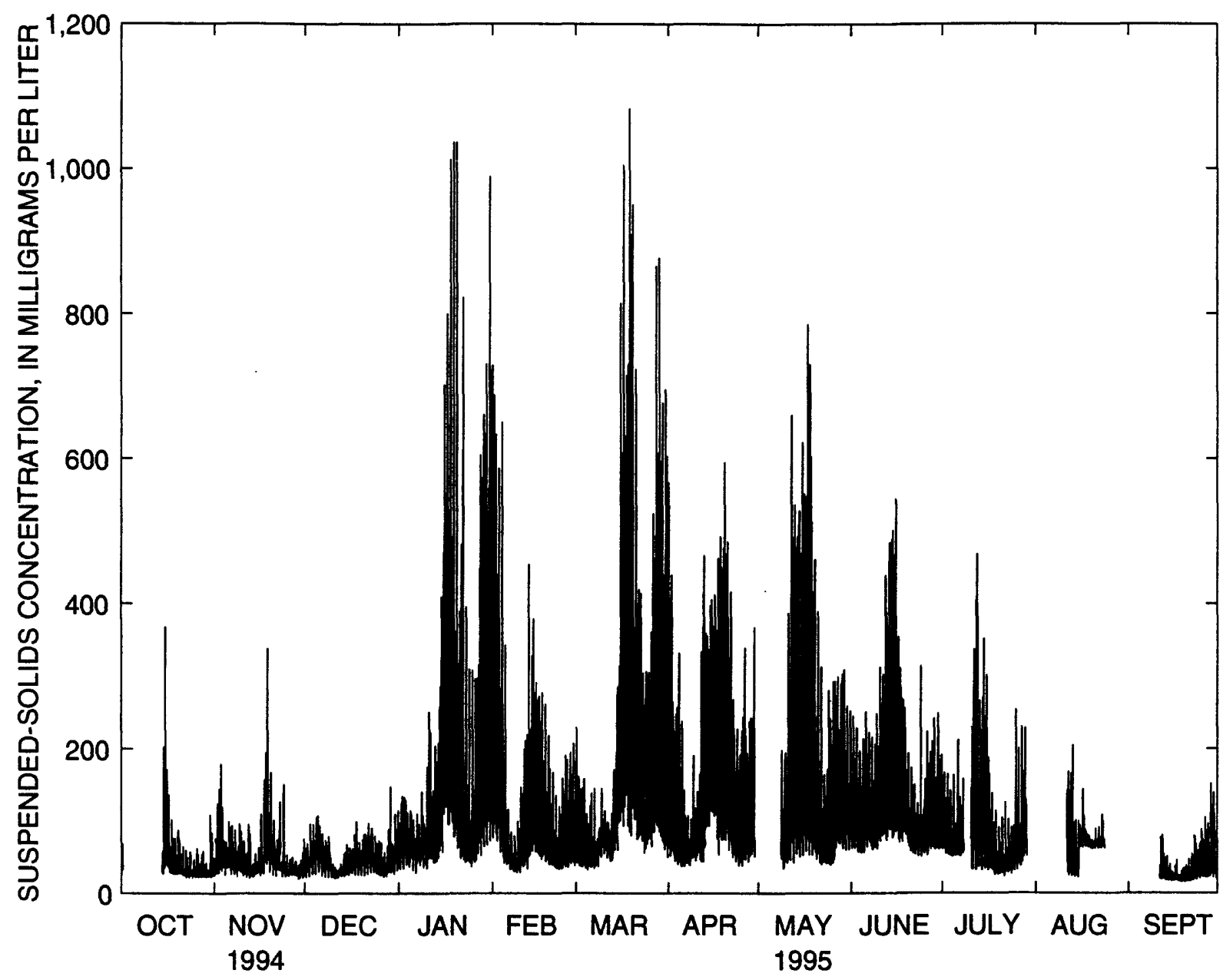

Figure 15. Time series of near-bottom suspended-solids concentration calculated from sensor readings at Point San Pablo, Central San Francisco Bay, Califomia, water year 1995. 


\section{Pier 24}

Calibration of the mid-depth sensor shifted in September 1994. The calibration used in water year 1995 was developed using 1 sample from September 1994 and 11 samples from water year 1995 and had a standard error of $12 \mathrm{mg} / \mathrm{L}$ (fig. 16). Shifts to the mid-depth record, calculated from water-sample data not shown on figure 16, were applied during the following periods: November 3 to December 20, 1994, March 29 to April 17, 1995, May 30 to June 22, 1995, and September 12-30, 1995. Calibration of the nearbottom sensor was developed from 25 samples taken from previous water years and 13 samples from water year 1995 and had a standard error of $16 \mathrm{mg} / \mathrm{L}$ (fig. 17). Shifts to the near-bottom record, calculated from water-sample data not shown on figure 17, were applied during the following periods: November 28, 1994, to January 17, 1995, and March 1 to May 8, 1995. Suspended-solids concentration data collected during water year 1995 are presented in figures 18 and 19.

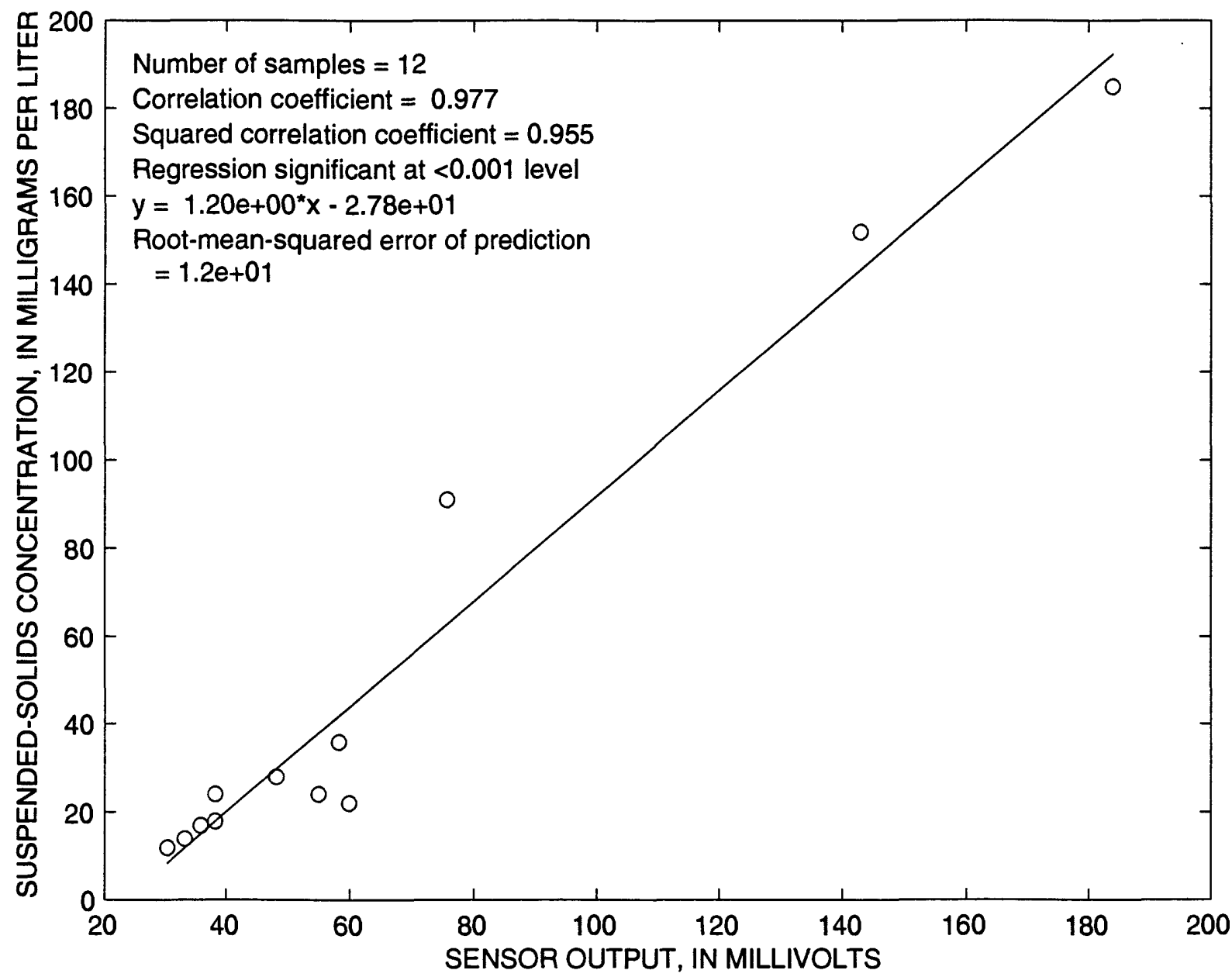

Figure 16. Calibration of mid-depth optical backscatterance sensor at Pier 24, Central San Francisco Bay, California, water year 1995. 


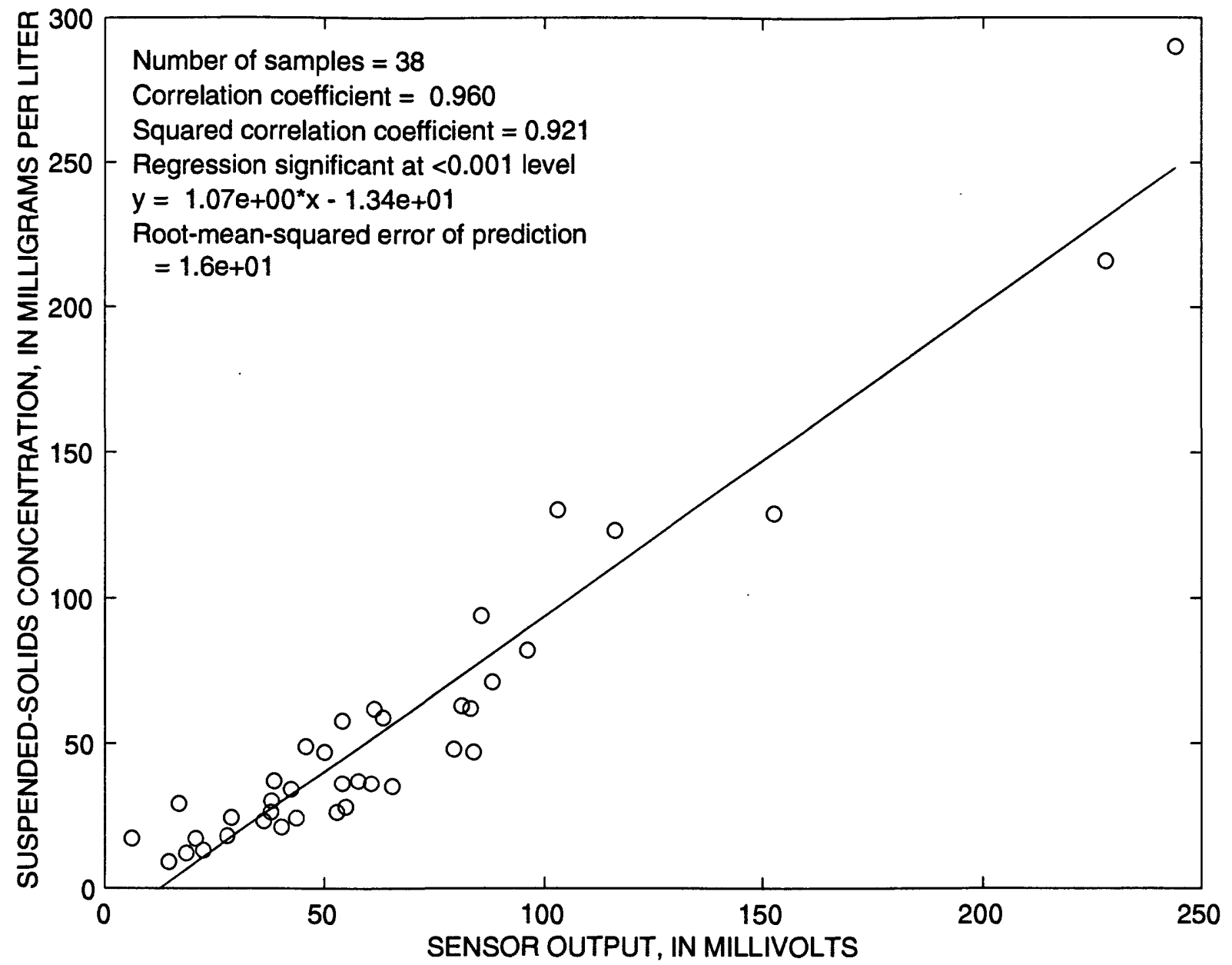

Figure 17. Calibration of near-bottom optical backscatterance sensor at Pier 24, Central San Francisco Bay, California, water year 1995. 


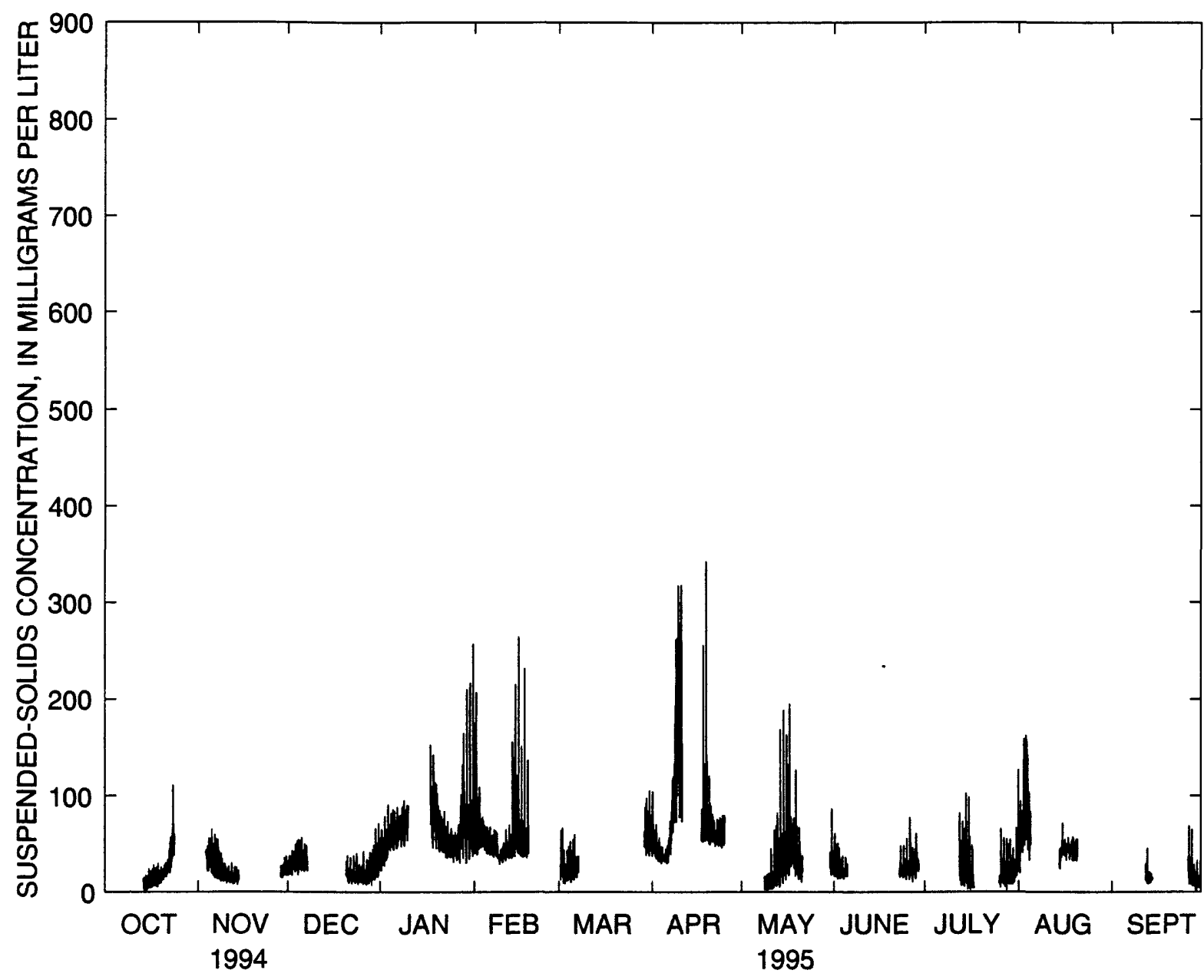

Figure 18. Time series of mid-depth suspended-solids concentration calculated from sensor readings at Pier 24, Central San Francisco Bay, California, water year 1995. 


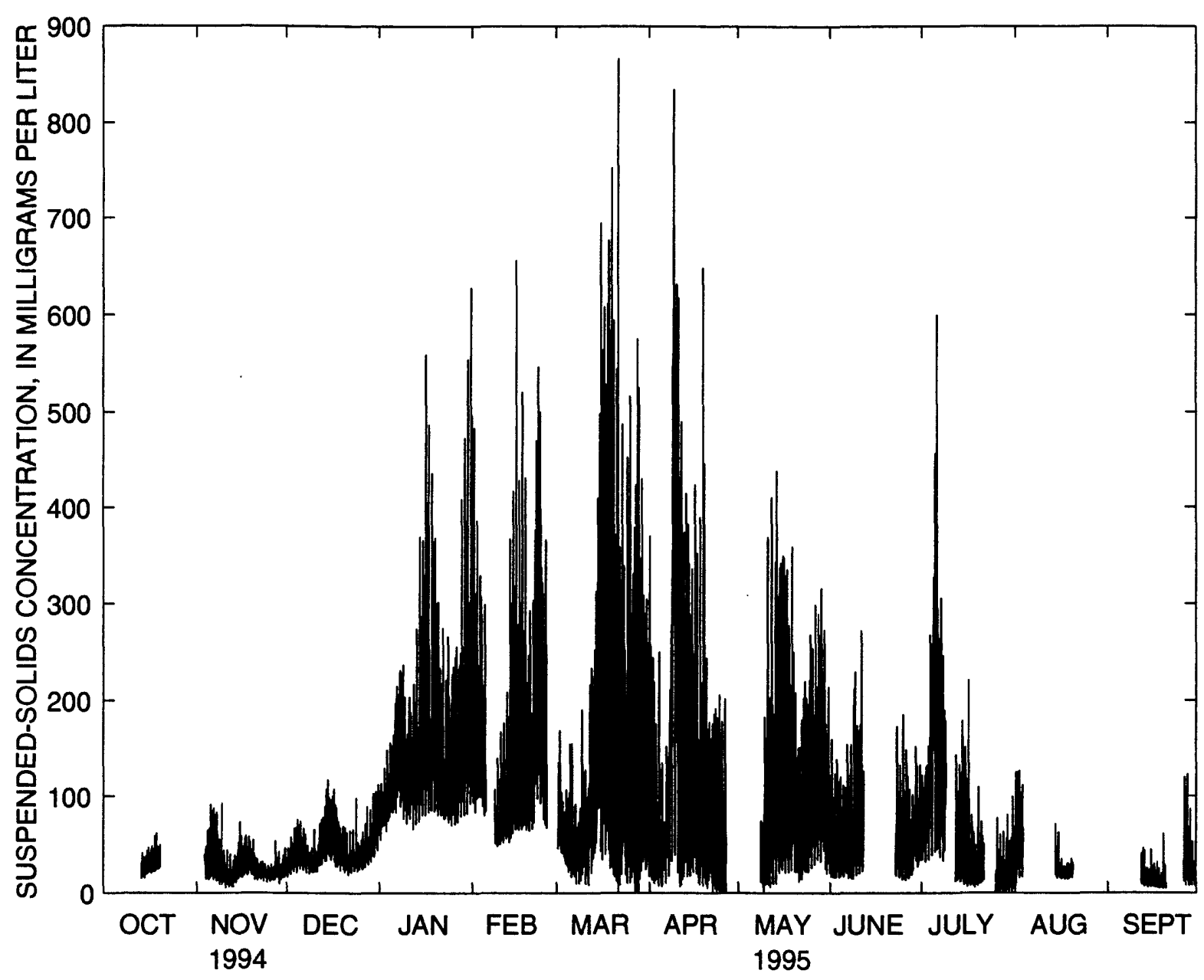

Figure 19. Time series of near-bottom suspended-solids concentration calculated from sensor readings at Pier 24, Central San Francisco Bay, Califomia, water year 1995. 


\section{South San Francisco Bay}

\section{Channel Marker 17}

The calibration of the mid-depth sensor is based on samples collected in water year 1995 and had a standard error of $22 \mathrm{mg} / \mathrm{L}$ (fig. 20). Comparisons with previous calibrations indicated that the slope of the calibration curve has slightly decreased with time. The calibration of the near-bottom sensor is based on samples collected in water year 1995 and had a standard error of $21 \mathrm{mg} / \mathrm{L}$ (fig. 21). The slope of the calibration of the near-bottom sensor has also decreased with time, as shown by comparisons with previous calibrations. During April 1995, high suspended-solids concentrations sometimes saturated the near-bottom sensor, which could measure a maximum concentration of approximately $1,700 \mathrm{mg} / \mathrm{L}$. The near-bottom sensor cable was damaged June 2 and caused a loss of data through July 26, 1995. Extreme fouling on both sensors caused a loss of data from August through the end of September 1995. Suspended-solids concentration data collected during water year 1995 are presented in figures 22 and 23.

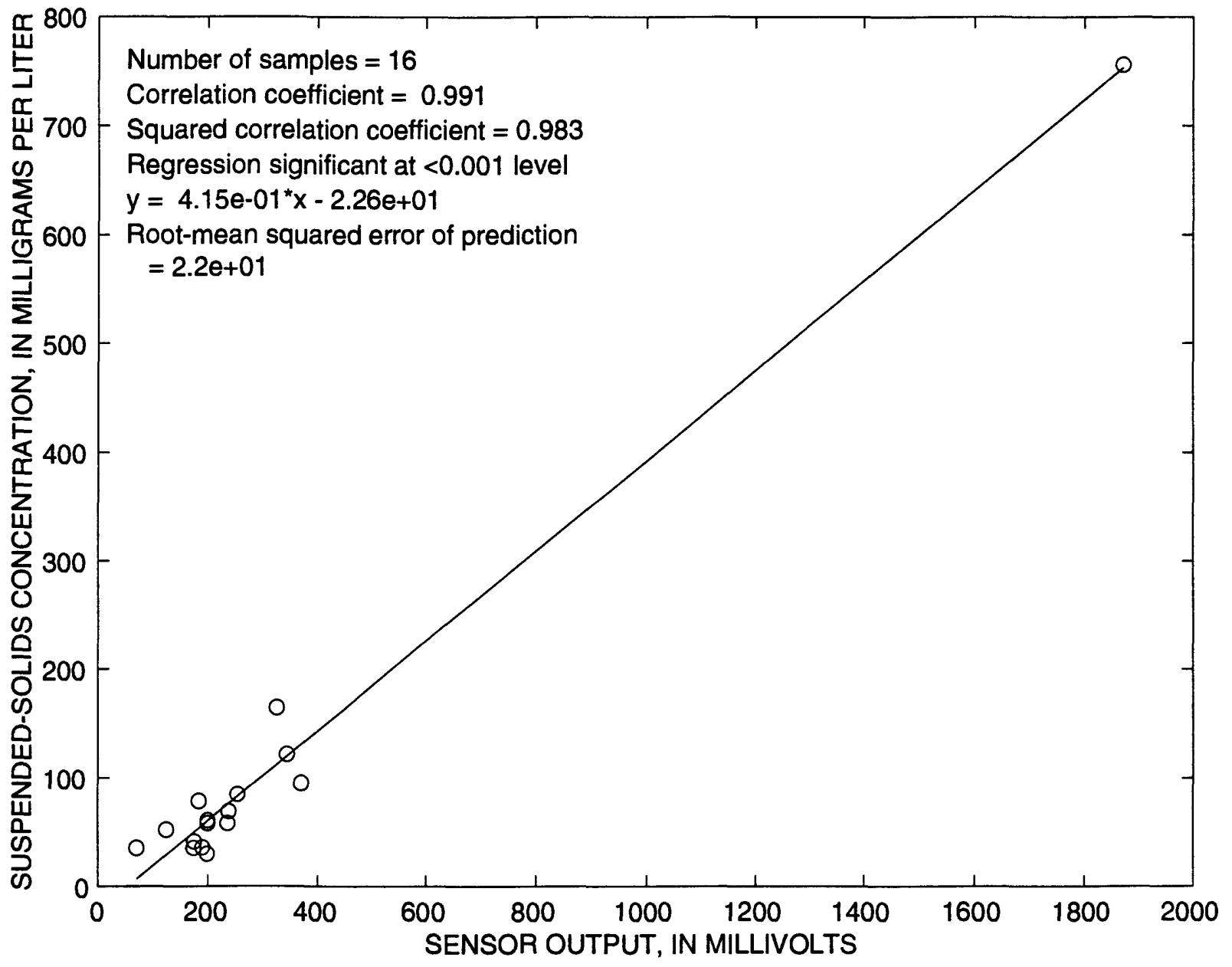

Figure 20. Calibration of mid-depth optical backscatterance sensor at channel marker 17, South San Francisco Bay, California, water year 1995. 


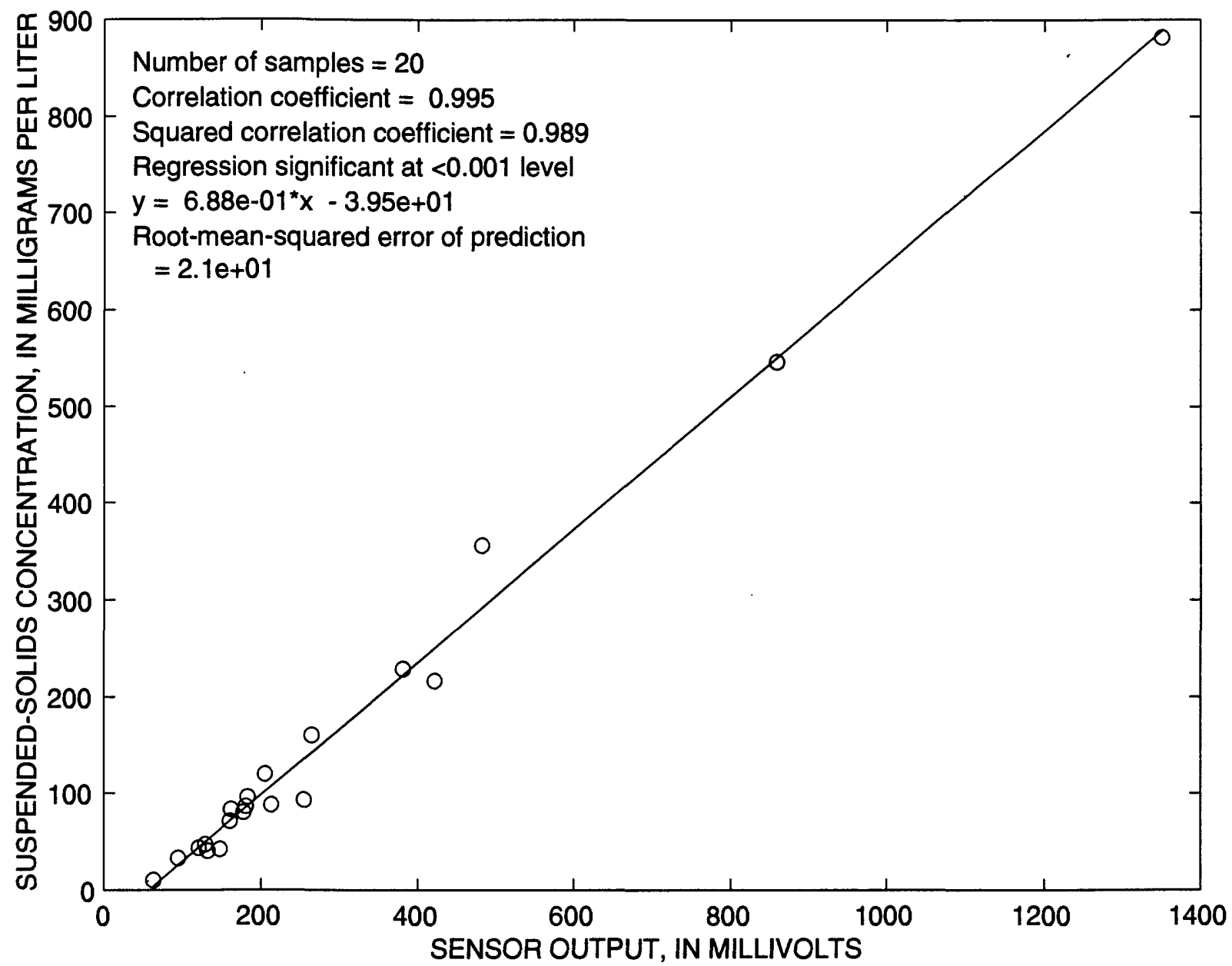

Figure 21. Calibration of near-bottom optical backscatterance sensor at channel marker 17, South San Francisco Bay, California, water year 1995. 


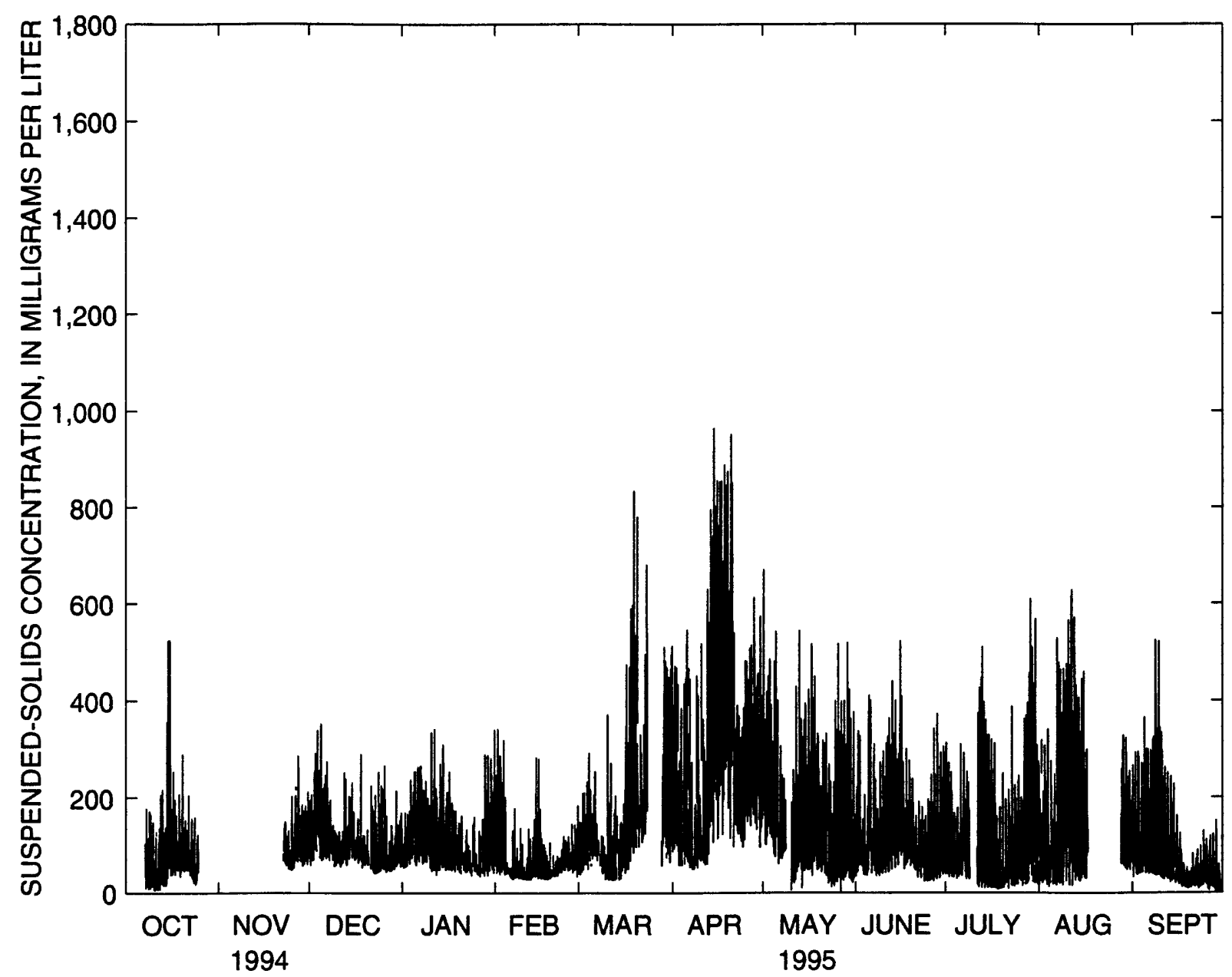

Figure 22. Time series of mid-depth suspended-solids concentration calculated from sensor readings at channel marker 17, South San Francisco Bay, Califomia, water year 1995. 


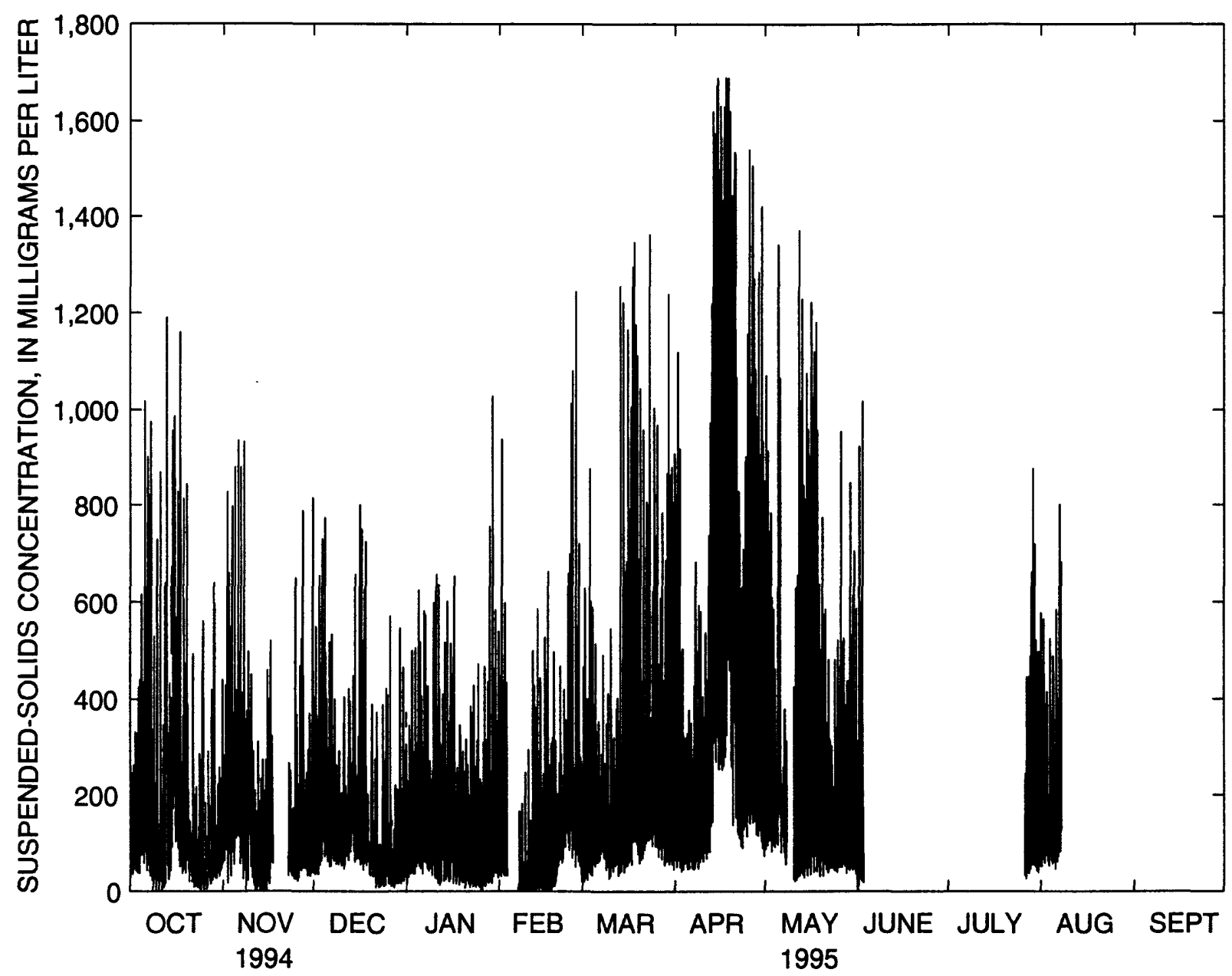

Figure 23. Time series of near-bottom suspended-solids concentration calculated from sensor readings at channel marker 17, South San Francisco Bay, California, water year 1995. 


\section{Dumbarton Bridge}

The calibration of the mid-depth wiper probe includes data from water year 1994 and had a standard error of $13 \mathrm{mg} / \mathrm{L}$ (fig. 24). The mid-depth wiper probe failed in May 1995 and was not replaced during the remainder of the water year. The calibration of the near-bottom wiper probe includes data from water year 1994 and had a standard error of $36 \mathrm{mg} / \mathrm{L}$ (fig. 25). The near-bottom wiper probe failed in July 1995 and was not replaced during the remainder of the water year. Suspended-solids concentration data collected in water year 1995 are presented in figures 26 and 27.

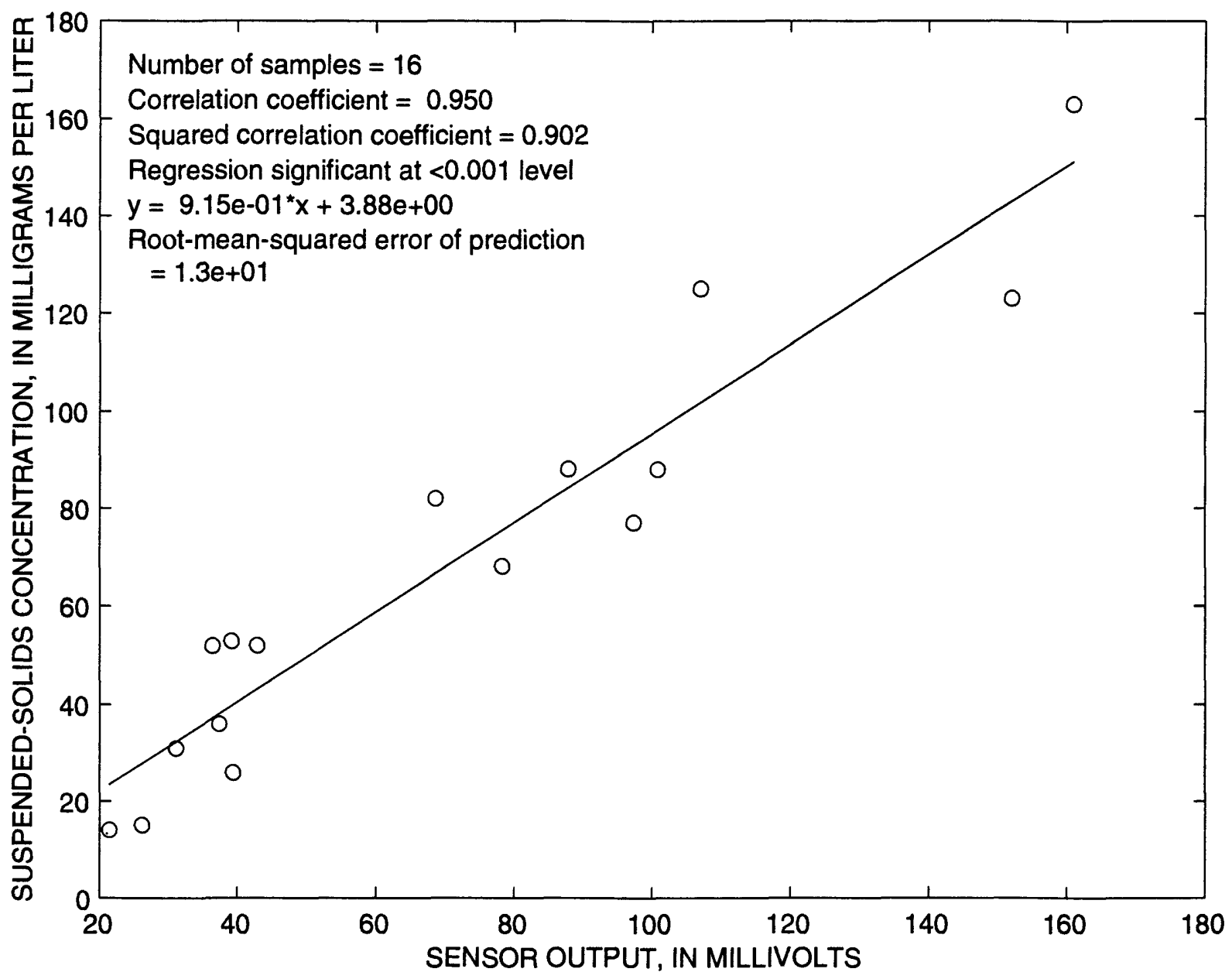

Figure 24. Calibration of mid-depth optical backscatterance sensor (with wiper) at Dumbarton Bridge, South San Francisco Bay, California, water year 1995. 


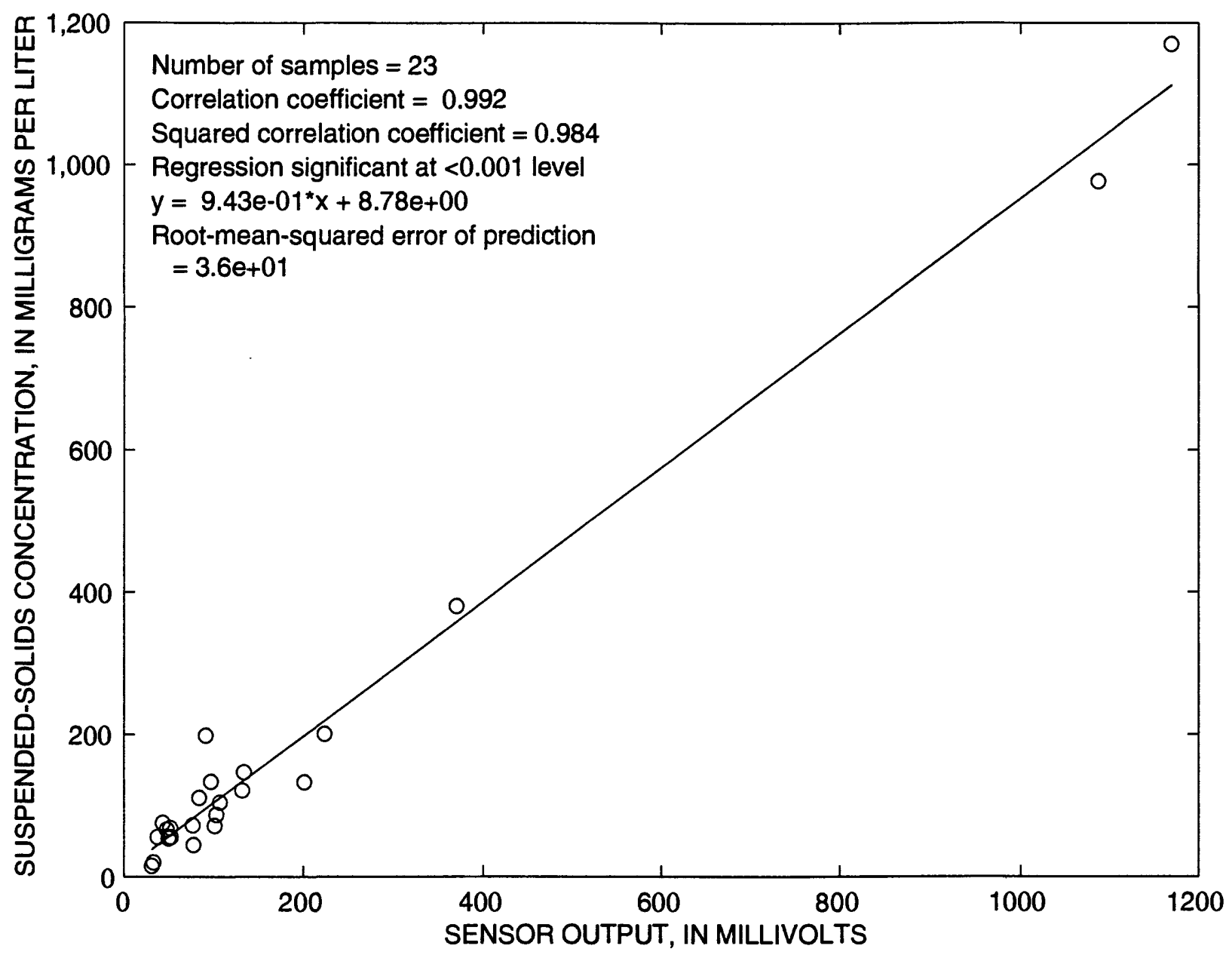

Figure 25. Calibration of near-bottom optical backscatterance sensor (with wiper) at Dumbarton Bridge, South San Francisco Bay, California, water year 1995. 


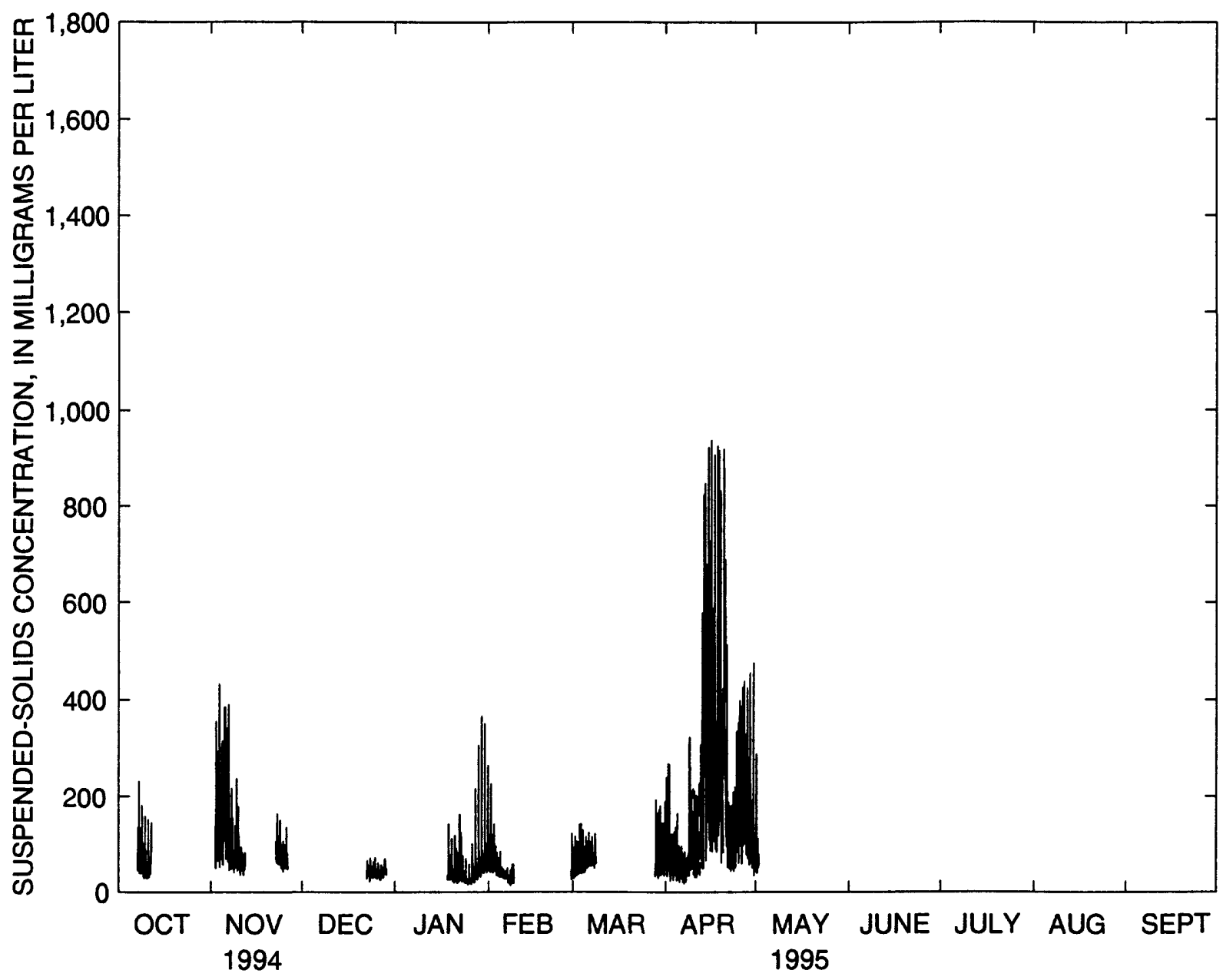

Figure 26. Time series of mid-depth suspended-solids concentration calculated from sensor readings at Dumbarton Bridge, South San Francisco Bay, California, water year 1995. 


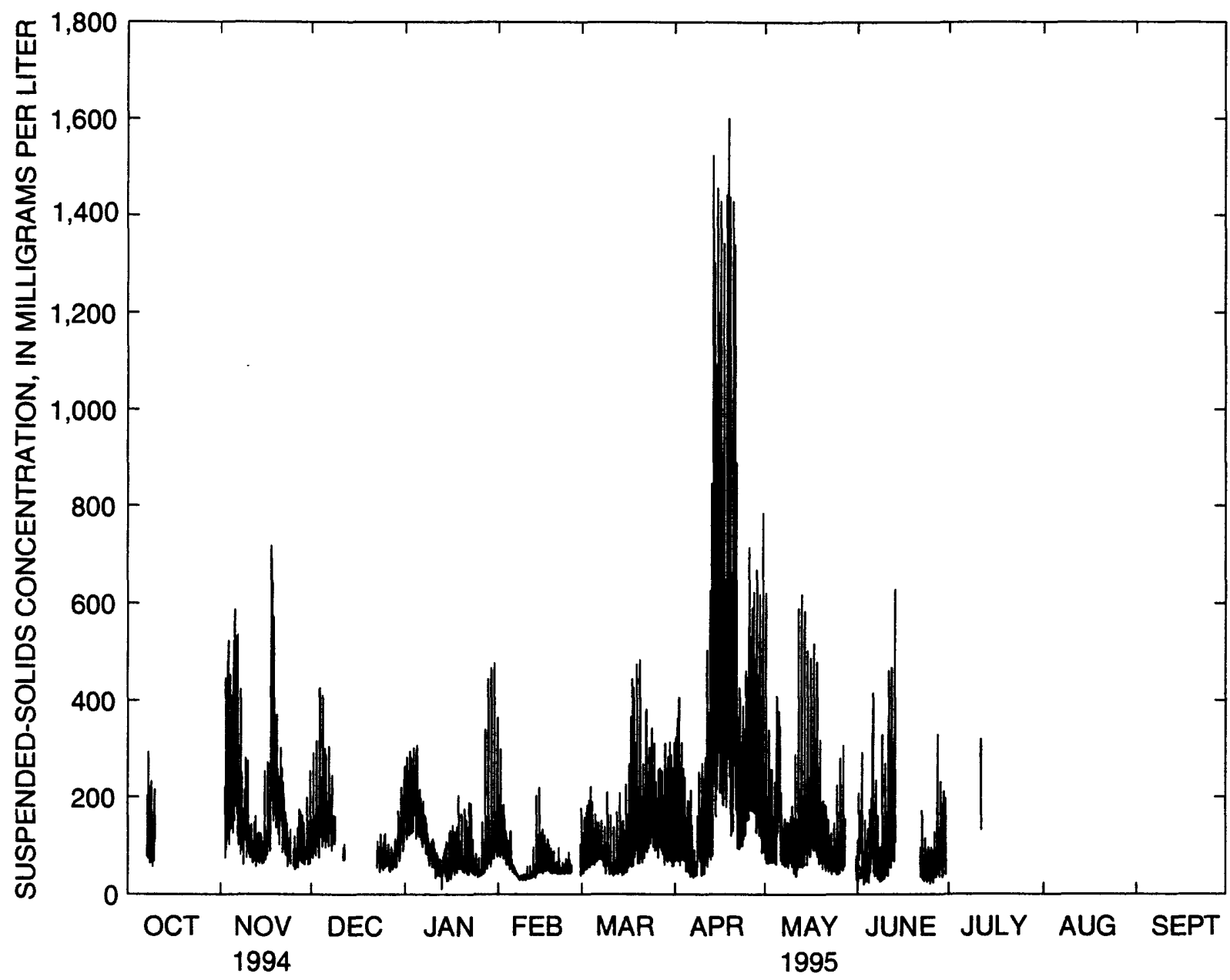

Figure 27. Time series of near-bottom suspended-solids concentration calculated from sensor readings at Dumbarton Bridge, South San Francisco Bay, California, water year 1995. 


\section{San Mateo Bridge}

On October 6, 1994, a new wiper probe was installed at the mid-depth position and operated properly until June 1995. The calibration of the mid-depth sensor had a standard error of $6.3 \mathrm{mg} / \mathrm{L}$ (fig. 28). The sensor was replaced on July 27, 1995, but failed 1 month later. An insufficient number of calibration samples were collected to calibrate the replacement sensor. On October 6, 1994, a new wiper probe was installed at the near-bottom position and operated properly until April 1995. The calibration for the near-bottom sensor had a standard error of $5.0 \mathrm{mg} / \mathrm{L}$ and is relatively poor because only a few low concentration samples were collected while the probe was operating (fig. 29). The near-bottom sensor was not replaced during the remainder of the water year. Suspended-solids concentration data collected during water year 1995 are presented in figures 30 and 31.

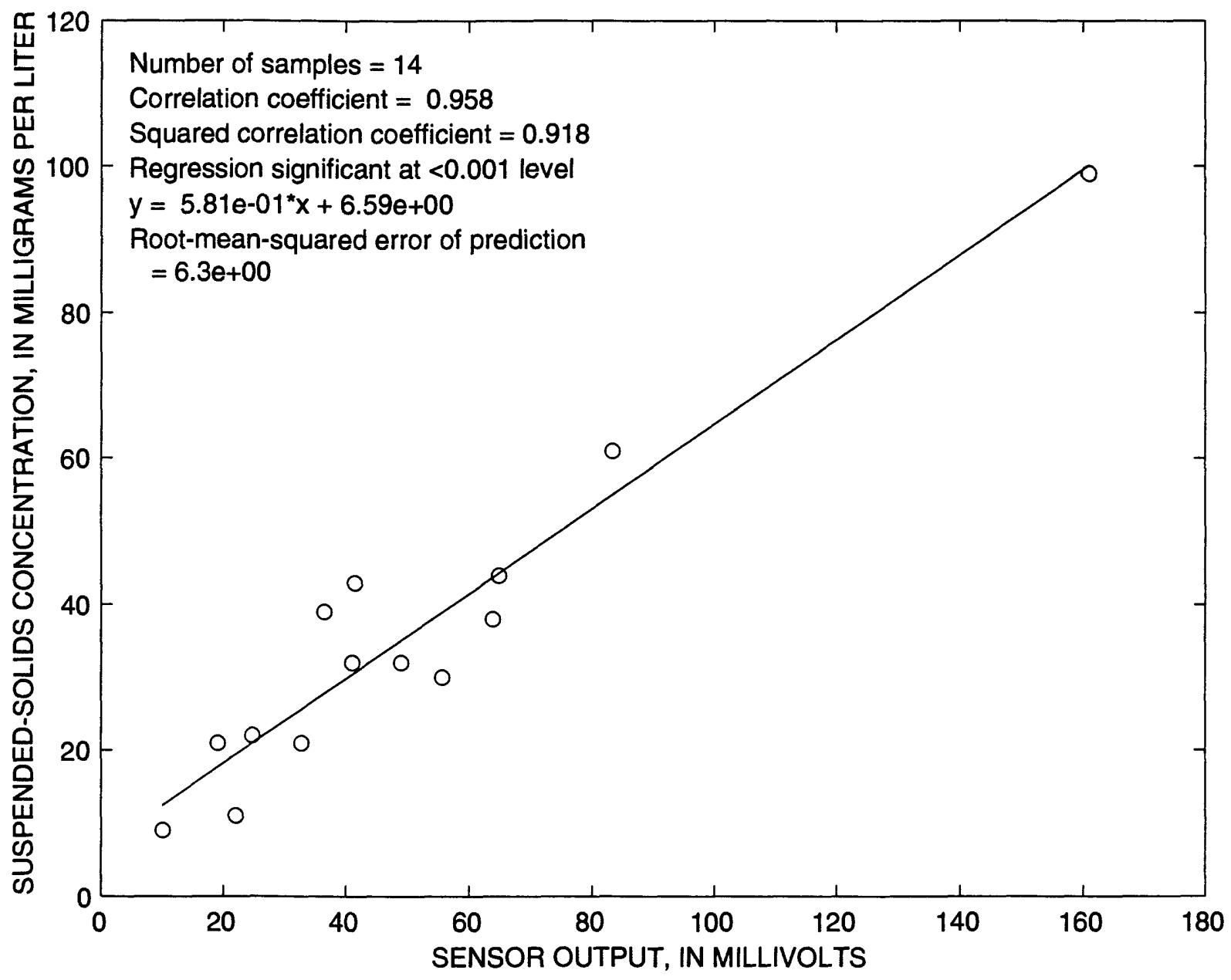

Figure 28. Calibration of mid-depth optical backscatterance sensor (with wiper) at San Mateo Bridge, South San Francisco Bay, California, water year 1995. 


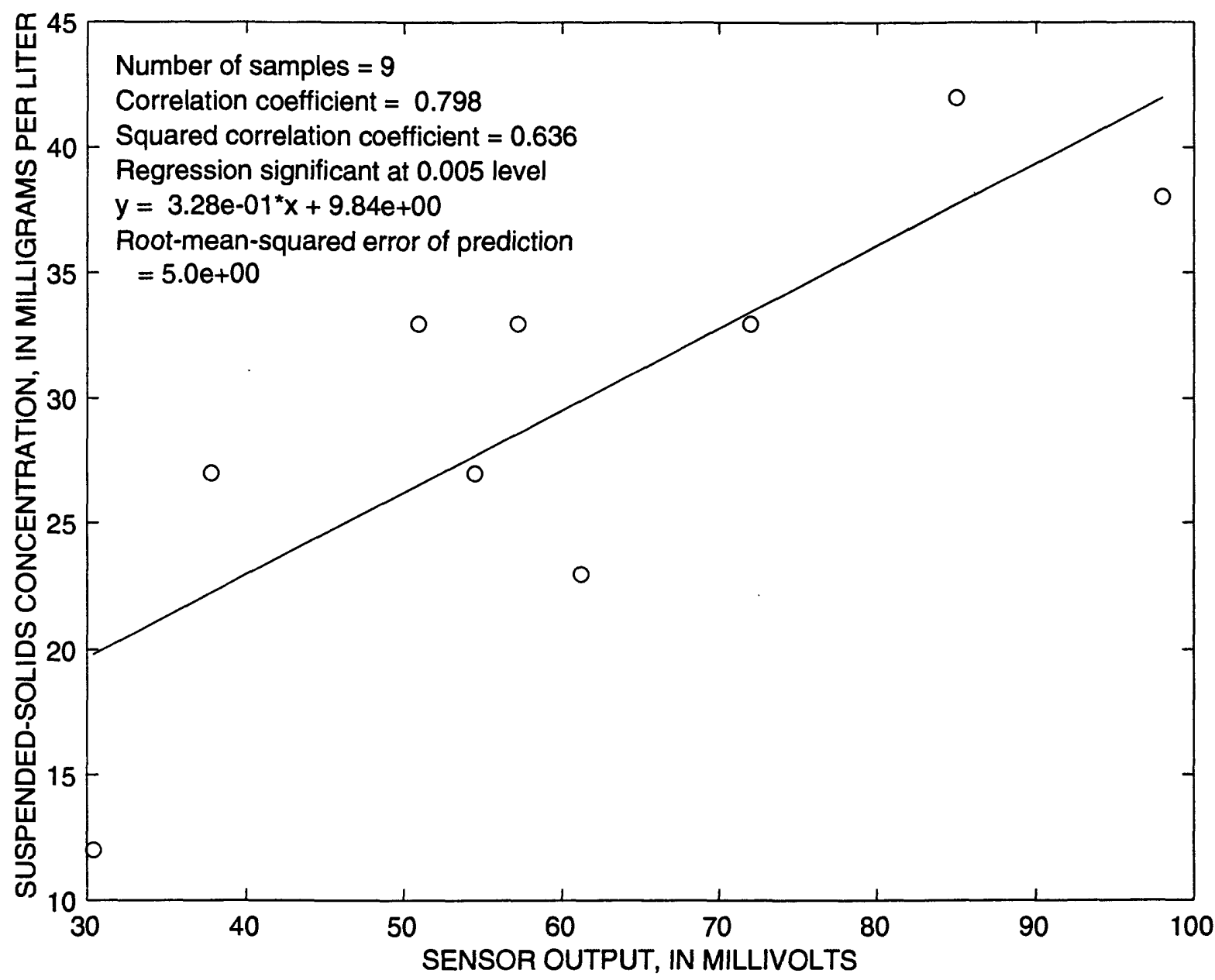

Figure 29. Calibration of near-bottom optical backscatterance sensor (with wiper) at San Mateo Bridge, South San Francisco Bay, California, water year 1995. 


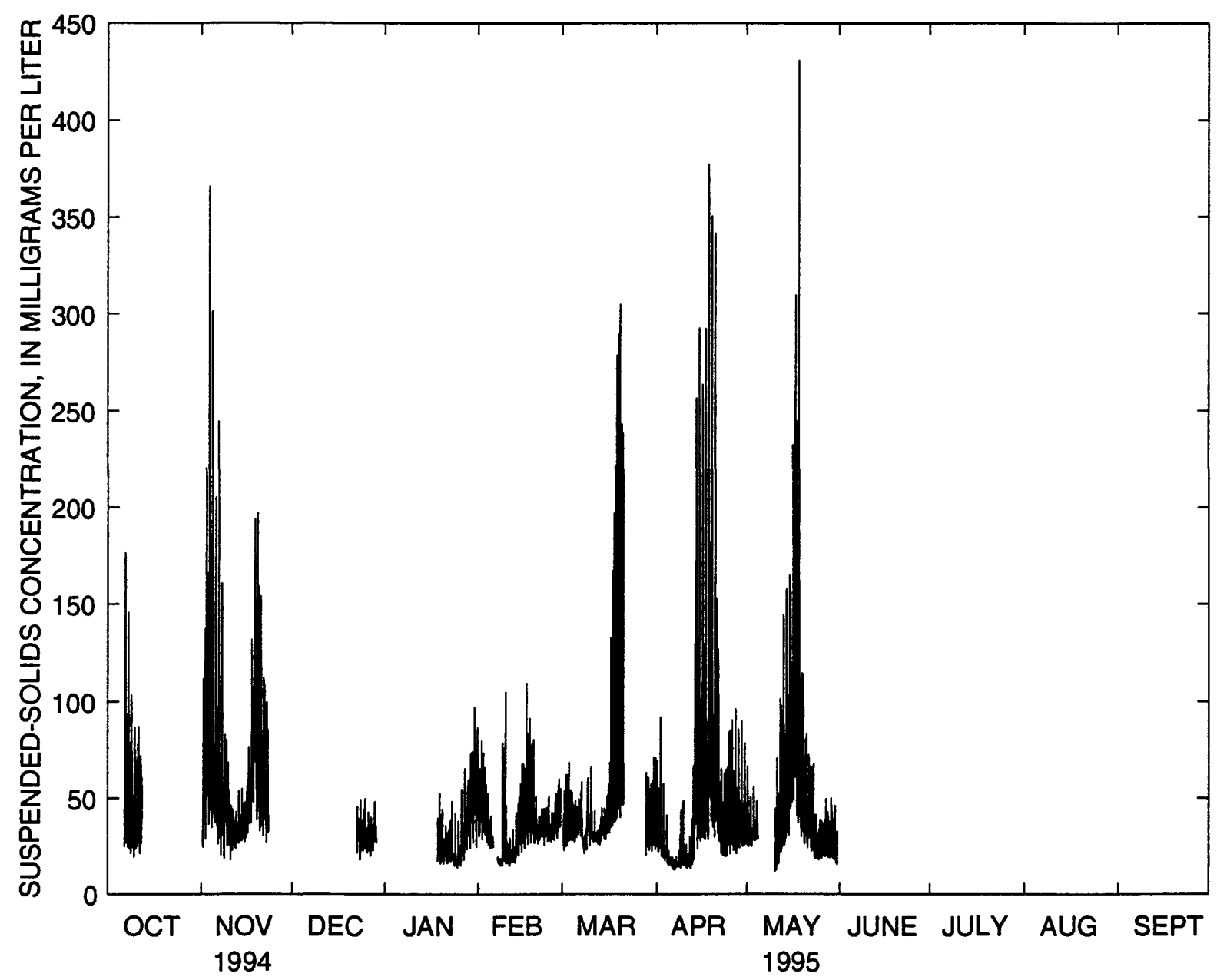

Figure 30. Time series of mid-depth suspended-solids concentration calculated from sensor readings at San Mateo Bridge, South San Francisco Bay, California, water year 1995. 


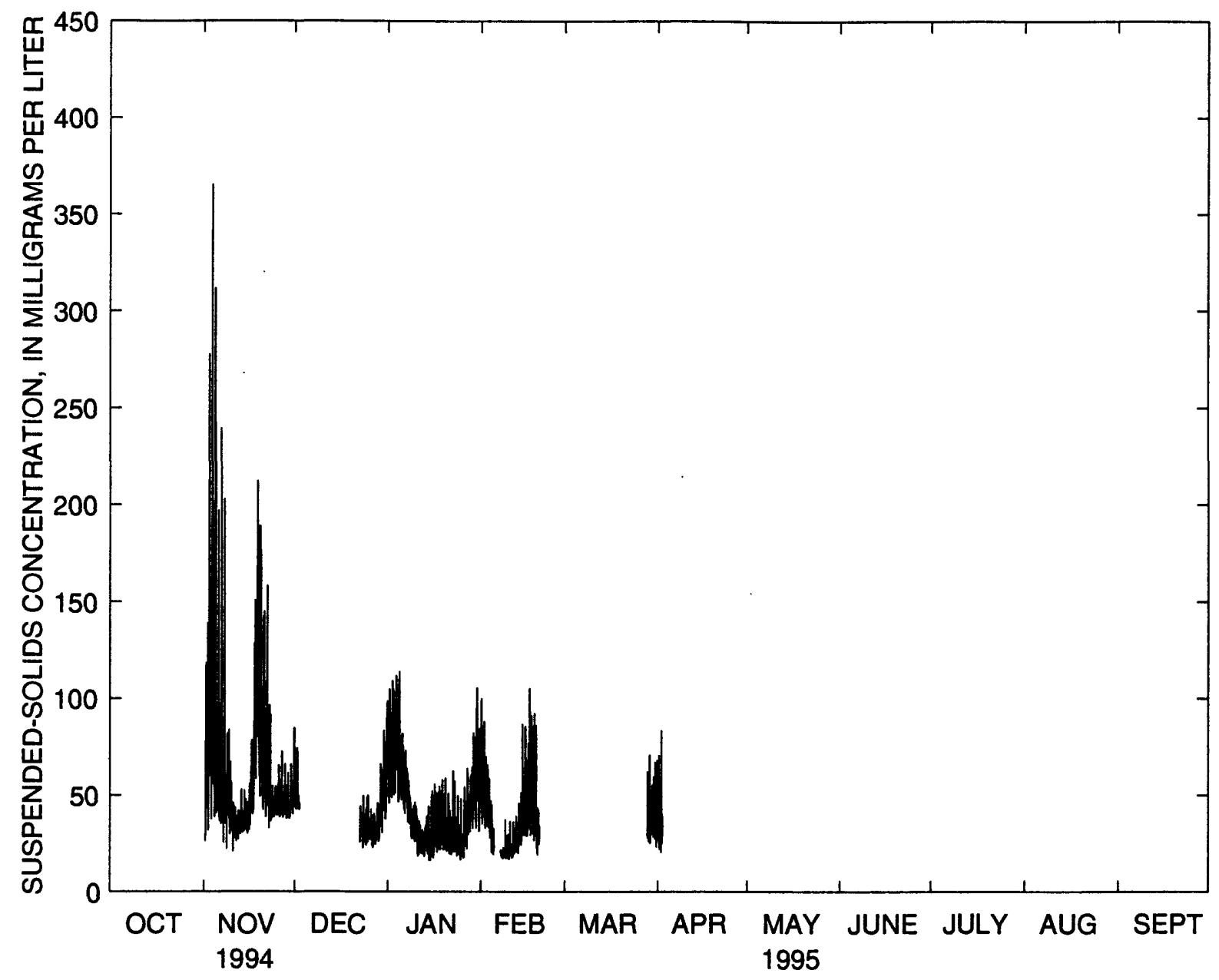

Figure 31. Time series of near-bottom suspended-solids concentration calculated from sensor readings at San Mateo Bridge, South San Francisco Bay, California, water year 1995. 


\section{SUMMARY}

Suspended-solids concentration data were collected by the U.S. Geological Survey (USGS) at two sites in Suisun Bay, two sites in Central San Francisco Bay, and three sites in South San Francisco Bay during water year 1995. Two types of optical backscatterance sensors, controlled by an electronic data logger, were used to monitor suspended solids. Water samples were collected to calibrate the electrical output of the optical sensors to suspended-solids concentration, and the recorded data were recovered and edited. Biological growth can foul optical sensors, and about half the data was invalidated by fouling. Complete data are available from the files of the USGS in Sacramento, California.

\section{REFERENCES}

Arthur, J.F., and Ball, M.D., 1979, Factors influencing the entrapment of suspended material in the San Francisco BayDelta Estuary, in Conomos, T.J., ed., San Francisco Bay: The urbanized estuary: San Francisco, Pacific Division of the American Association for the Advancement of Science, p. 143-174.

Brown, C.L., and Luoma, S.N., 1995, Use of the euryhaline bivalve Potamocorbula amurensis as a biosentinal species to assess trace metal contamination in San Francisco Bay: Marine Ecology Progress Series, v. 124, p. 129-142.

Buchanan, P.A., and Schoellhamer, D.H., 1995, Summary of suspended-solids concentration data, Central and South San Francisco Bays, California, water years 1992 and 1993: U.S. Geological Survey Open-File Report 94-543, $15 \mathrm{p}$.

Buchanan, P.A., Schoellhamer, D.H., and Sheipline, R.C., 1996, Summary of suspended-solids concentration data, San Francisco Bay, California, water year 1994: U.S. Geological Survey Open-File Report 95-776, 48 p.

Carlson, P.R., and McCulloch, D.S., 1974, Aerial observations of suspended-sediment plumes in San Francisco Bay and adjacent Pacific Ocean: Journal of U.S. Geological Survey Research, v. 2, no. 5, p. 519-526.

Cloern, J.E., 1987, Turbidity as a control on phytoplankton biomass and productivity in estuaries: Continental Shelf Research, v. 7, no. 11/12, p. 1367-1381.

Cole, B.E., and Cloern, J.E., 1987, An empirical model for estimating phytoplankton productivity in estuaries: Marine Ecology Progress Series, v. 36, p. 299-305.

Conomos, T.J., and Peterson, D.H., 1977, Suspended-particle transport and circulation in San Francisco Bay, an overview: New York, Academic Press, Estuarine Processes, v. 2, p. 82-97.

Domagalski, J.L., and Kuivila, K.M., 1993, Distributions of pesticides and organic contaminants between water and suspended sediment, San Francisco Bay, California: Estuaries, v. 16, no. 3A, p. 416-426.

Downing, J.P., 1983, An optical instrument for monitoring suspended particulates in ocean and laboratory, in OCEANS 1983, San Francisco, California, August 29-September 1, 1983, Proceedings: p. 199-202.

Downing, J.P., Sternburg, R.W., and Lister, C.R.B., 1981, New instrumentation for the investigation of sediment suspension processes in the shallow marine environment: Marine Geology, v. 42, p. 19-34.

Fishman, M.J., and Friedman, L.C., 1989, Methods for determination of inorganic substances in water and fluvial sediments: U.S. Geological Survey Techniques of Water-Resources Investigations, book 5, chap. A1, 545 p.

Hammond, D.E., Fuller, C., Harmon, D., Hartman, B., Korosec, M., Miller, L.G., Rea, R., Warren, S., Berelson, W., and Hager, S.W., 1985, Benthic fluxes in San Francisco Bay: Hydrobiologia, v. 129, p. 69-90.

Jassby, A.D., and Powell, T.M., 1994, Hydrodynamic influences on interannual chlorophyll variability in an estuary: Upper San Francisco Bay-Delta (California, U.S.A.): Estuarine, Coastal and Shelf Science, v. 39, p. 595-618.

Kimmerer, W., 1992, An evaluation of existing data in the entrapment zone of the San Francisco Bay Estuary: Tiburon, California, Biosystems Analysis, Inc., Technical Report 33, 49 p.

Kuwabara, J.S., Chang, C.C.Y., Cloern, J.E., Fries, T.L., Davis, J.A., and Luoma, S.N., 1989, Trace metal associations in the water column of South San Francisco Bay, California: Estuarine, Coastal and Shelf Science, v. 28, p. 307325.

Lacy, J.R., Schoellhamer, D.H., and Burau, J.R., 1996, Suspended-solids flux at a shallow water site in South San Francisco Bay, California: Proceedings of the North American Water and Environment Congress, June 24-28, 1996, Anaheim, California. 
Levesque, V.A., and Schoellhamer, D.H., 1995, Summary of sediment resuspension monitoring, Old Tampa Bay and Hillsborough Bay, Florida, 1988-91: U.S. Geological Survey Water-Resources Investigations Report 94-4081, $31 \mathrm{p}$.

Luoma, S.N., Cain, D., and Johansson, C., 1985, Temporal fluctuations of silver, copper, and zinc in the bivalve Macoma balthica at five stations in South San Francisco Bay: Hydrobiologia, v. 129, p. 109-120.

Peterson, D.H., Conomos, T.J., Broenkow, W.W., and Doherty, P.C., 1975, Location of the non-tidal current null zone in northern San Francisco Bay: Estuarine and Coastal Marine Science, v. 3, p. 1-11.

Porterfield, G., 1980, Sediment transport of streams tributary to San Francisco, San Pablo, and Suisun Bays, California, 1909-1966: U.S. Geological Survey Water-Resources Investigations 80-64, 91 p.

Powell, T.M., Cloern, J.E., and Huzzey, L.M., 1989, Spatial and temporal variability in South San Francisco Bay (U.S.A.). I. Horizontal distributions of salinity, suspended sediments, and phytoplankton biomass and productivity: Estuarine, Coastal and Shelf Science, v. 28, p. 583-597.

Schoellhamer, D.H., 1996, Factors affecting suspended-solids concentrations in South San Francisco Bay, California: Journal of Geophysical Research, v. 101, no. C5, p. 12087-12095.

Smith, L.H., 1987, A review of circulation and mixing studies of San Francisco Bay, California: U.S. Geological Survey Circular 1015, $38 \mathrm{p}$.

Tobin, A., Schoellhamer, D.H., and Burau, J.R., 1995, Suspended-solids flux in Suisun Bay, California, in First International Conference of Water Resources Engineering, San Antonio Texas, August 14-18, 1995, Proceedings: New York, American Society of Civil Engineers, p. 1511-1515.

U.S. Environmental Protection Agency, 1992, State of the estuary: Dredging and waterway modification: U.S. Environmental Protection Agency San Francisco Estuary Project, chap. 8, p. 191-215. 